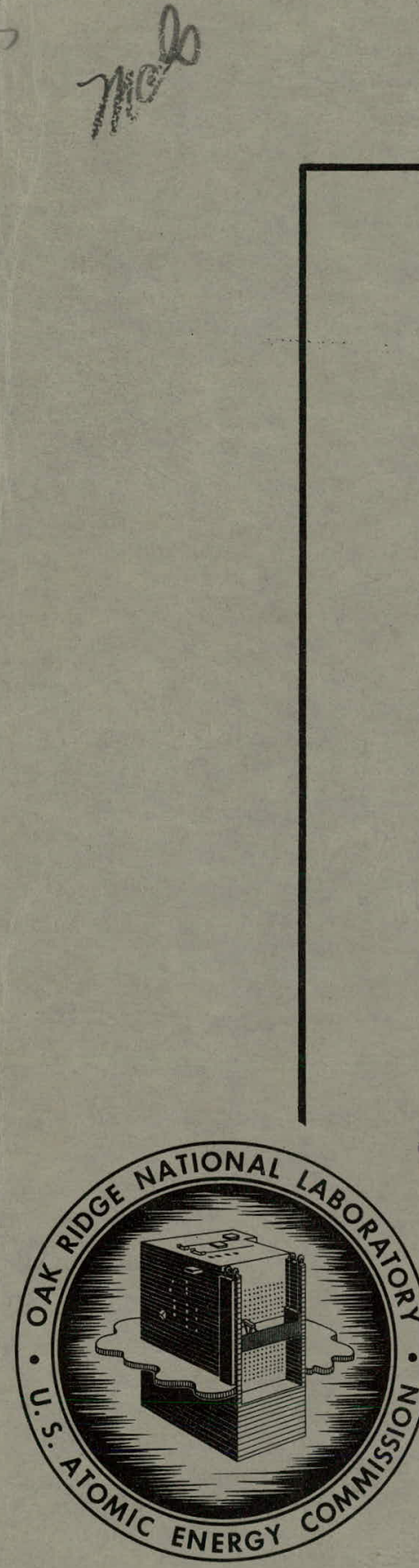

\title{
CHEMICAL TECHNOLOGY DIVISION \\ UNIT OPERATIONS SECTION \\ MONTHLY PROGRESS REPORT
}

SEPTEMBER 1958

Central Files Number

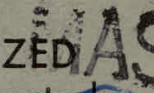

STER Distribution Limited to Recipients Indicated.

$58-9-62$

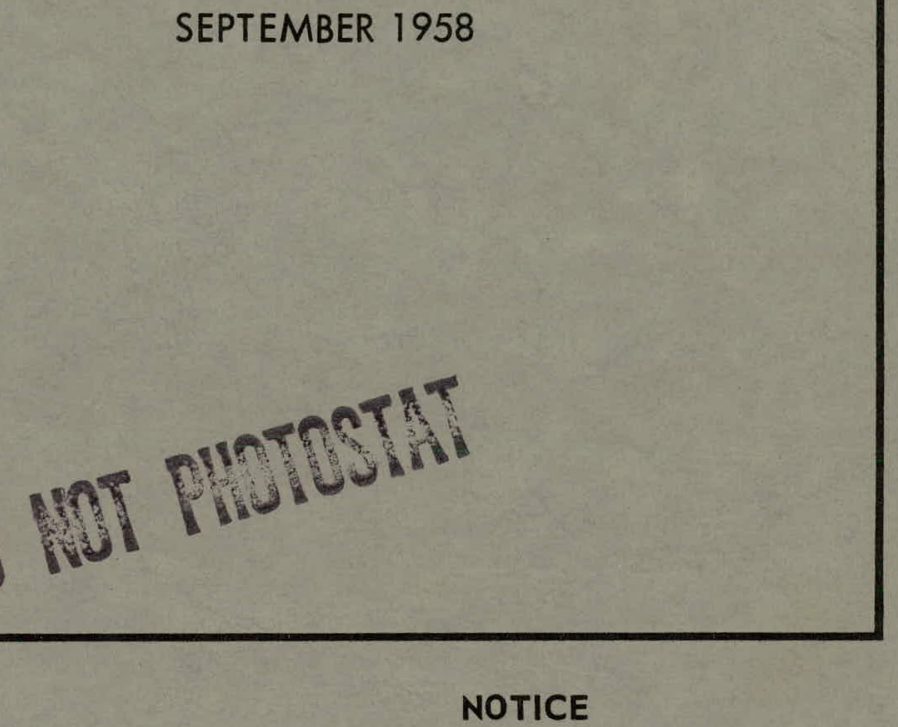

This document contains information of a preliminary nature and was prepared primarily for internal use at the Oak Ridge National Laboratory. It is subject to revision or correction and therefore does not represent a final report. The information is not to be abstracted, reprinted or otherwise given public dissemination without the approval of the ORNL patent branch, Legal and Information Control Department.

OAK RIDGE NATIONAL LABORATORY

operated by

UNION CARBIDE CORPORATION

for the

U.S. ATOMIC ENERGY COMMISSION

RELEASE APPROYED 


\section{DISCLAIMER}

This report was prepared as an account of work sponsored by an agency of the United States Government. Neither the United States Government nor any agency Thereof, nor any of their employees, makes any warranty, express or implied, or assumes any legal liability or responsibility for the accuracy, completeness, or usefulness of any information, apparatus, product, or process disclosed, or represents that its use would not infringe privately owned rights. Reference herein to any specific commercial product, process, or service by trade name, trademark, manufacturer, or otherwise does not necessarily constitute or imply its endorsement, recommendation, or favoring by the United States Government or any agency thereof. The views and opinions of authors expressed herein do not necessarily state or reflect those of the United States Government or any agency thereof. 


\section{DISCLAIMER}

Portions of this document may be illegible in electronic image products. Images are produced from the best available original document. 
EXTERNAL TRANSMITTAL AUTHORIZED EISTRIBUTION ITMIYTH RHEIPIETS INDICAFPED

ORNL CF NO. 58-9-62

UNIT OPERATIONS SECTION MONTHLY PROGRESS REPORT

September 1958

CHEMICAL TECHNOLOGY DIVISION
J. C. Bresee
P. A. Haas
C. D. Watson
M. E. Whatley

Date Issued

NOV 181958

OAK RIDGE INATIONAL LABORATORY

Oak Ridge, Tennessee

Operated By

UNION CARBIDE CORPORATION

for the

U. S. Atomic Energy Commission 
The feasibility was demonstrated of the use of liquidorganic scintillators in contact with an alpha emitting aqueous phase for the measurement of interfacial area in a mixer. The transpiration flow of pure water reduced the corrosion by a factor of 60 of a porous nickel tube by $\mathrm{FeCl}_{3}$. One continuous DRUHM reaction study was made in which poor product consolidation resulted from a less than optimum sodium feed rate. In Fluorox run FBR-19, an over-all material balance of 102 per cent and $a U_{6}$ balance of 97 per cent was obtained, with a $U_{6}$ recovery of 71 per cent. The flame denitration of a thorium-uranium nitrate solution in an oxygen acetylene flame was carried out successfully to produce a mixed oxide of 1.5 micron mean particle size with a surface area of $5.8 \mathrm{sq}$. meters per gram. Cylindrical hydroclones were tested for the collection of circulating thoria slurries. In the determination of the uranium loading of anion exchange resin a predicted maximum loading at a sulfate concentration of approximately $0.04 \mathrm{M}$ was not found in preliminary experiments. A continuous Dārex run was carried out with sections of prototype APPR plates and was frequently interrupted due to the deposition of siliceous material in the stripping column. A Zircex run was carried out with commercially available $\mathrm{HCl}$ gas containing oxygen rather than carbon dioxide as the major impurity, resulting in comparable uranium losses due to the formation of aqueous insoluble oxide solids. Simulated " 25 " waste was evaporated as a neutralized and unneutralized solution, giving condensates which were $0.5 \mathrm{M}$ and $4 M$ in acid, respectively. 
CONTENTS

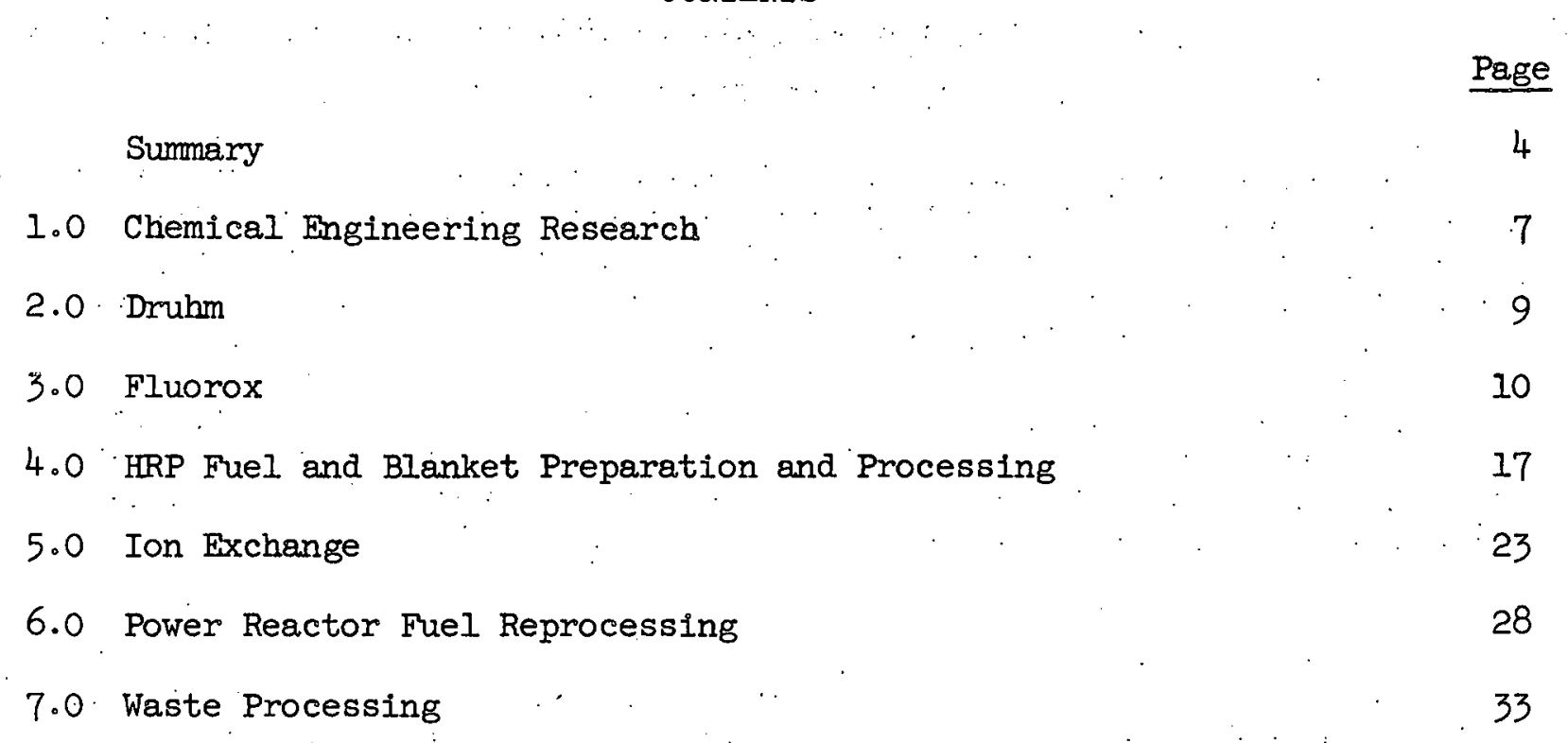




\subsection{CHEMICAL ENGINEERING RESEARCH}

Preliminary results were obtained from measurements of interfacial areas by use of liquid-organic scintillators in contact with an alpha-emitting aqueous phase. Variations of interfacial area with mixer operating conditions were easily measured; however, an accurate calibration has not been made since obtaining a large known area of interface is difficult.

Experimental studies of protection of a porous nickel wall from corrosion by $\mathrm{FeCl}_{3}$ by using a transpirational flow of pure $\mathrm{H}_{2} \mathrm{O}$ were completed. The results are being correlated for comparison with proposed corrosion reaction mechanisms and with previously developed film theories.

\subsection{DRUHM}

One continuous reaction run was made; however, a malfunction in the sodium metering system prevented attainment of the optimum sodium flow rate and the experimental results were not useful.

A tungsten nozzle for $\mathrm{UF}_{6}$ feed to the reactor is being fabricated and will be used for the next continuous reaction run.

\subsection{FLUOROX}

Experimental and analytical results from run FBR-19 were evaluated. The over-all material balance was 101.7 per cent with a UF 6 balance of.97.0 per cent and a UF, recovery in the chemical and cold traps of 70.8 per cent. An attempted run (FBR-20) in the 4-in. dia reactor was unsuccessful, lasting for $4 \mathrm{hr}$ during which there were frequent losses of fluidization gas flow. Modifications are being made to correct this difficulty.

\subsection{HR FUEL AND BLANKET PREPARATION AND PROCESSING}

Several torch-feed assemblies were tested and a design was developed which operates smoothly for the flame denitration of thorium-uranium nitrate solutions in an $\mathrm{O}_{2}-\mathrm{C}_{2} \mathrm{H}_{2}$ flame. Mixed oxide of 1.5 micron mean diameter, 85 wt per cent below 5 microns, and $5.8 \mathrm{sq} \cdot \mathrm{m} / \mathrm{g}$ surface area was classified for removal of over 5 micron material and submitted for toroid testing. Reflectors of $\mathrm{MgO}$ appear excellent for temperatures up to $1600^{\circ} \mathrm{C}$, but fail before $2000^{\circ} \mathrm{C}$ is reached. Fluidized bed equipment installed for direct denitration of $\mathrm{Th}\left(\mathrm{NO}_{3}\right)_{4}$ solutions operated well with an initial $\mathrm{ThO}_{2}$ charge and sprayed $\mathrm{H}_{2} \mathrm{O}$ as the feed stream. Feed system modifications were necessary to permit successfully feeding of $\mathrm{Th}\left(\mathrm{NO}_{3}\right)_{4}$ solutions.

Cylindrical hydroclones were tested for application to collection of circulating $\mathrm{ThO}_{2}$ slurries into an induced underflow receiver. While conical hydroclones are more efficient, the cylindrical design would reduce plugging of the underflow port during operation with $\mathrm{ThO}_{2}$ slurries with

\footnotetext{
: 98
} 
abnormal properties. A high pressure bydroclone of $3.5 \mathrm{in.} \mathrm{dia} \mathrm{was} \mathrm{designed}$ to permit testing of large capacity processing to remove over 5 micron corrosion products.

\subsection{ION EXCHANGE}

Several runs were made to determine the resin uranium loading in equilibrium with $0.005 \mathrm{M}$ uranyl sulfate solutions containing different total sulfate concentrations: A maximum loading was expected with solutions having a sulfate concentration of approximately $0.04 \mathrm{M}$; however, the data obtained thus far do not indicate that a maximum occurs anywhere above a sulfate concentration of $0.03 \mathrm{M}$. Since it is desirable to determine if a maximum loading occurs and to evaluate the $\mathrm{UO}_{2}^{++}-\mathrm{SO}_{4}$ association constants, investigations at low sulfate concentrations will be made.

\subsection{POWER REACTOR FUEL REPROCESSING}

Based on a single Zircex run, it appears that $\mathrm{CO}_{2}$ as an impurity in the HCl gas gives slightly higher uranium losses (due to formation of aqueous insoluble solids) than $\mathrm{O}_{2}$.

A method was developed for separating and collecting the solids (for analysis) obtained during dejacketing studies of prototype PWR blanket elements.

Twenty-six prototype Consolidated Edison fuel jackets have been fabricated to be loaded with $\mathrm{ThO}_{2}-\mathrm{UO}_{2}$ pellets and irradiated, preparatory to dissolution studies. Other fuel pins are currently belng autoclaved at $300^{\circ} \mathrm{C}$ and 200 psig to produce an oxide coating similar to irradiated pins. These will also be used for dissolution studies.

Detailed sketches of a SRE fuel decladding device are being drawn.

The 2-in. dia glass extraction column in Building 3503 has been converted from a sieve plate pulse column to a packed column preparatory to making some runs on simulated power reactor fuel feed solutions, using a Redox type flowsheet (hexone as the solvent). These runs will assist Hanford in using their Redox plant for power reactor fuel reprocessing on a part-time basis.

A 13-1/2 hr Darex integrated loop run was made using sections of prototype APPR plates, but was intermupted 3 times due to siliceous material from the stainless steel coating the interior of the stripping column. Steady-state operation was never obtained. The siliceous coating can easily be removed with hot $2 \mathrm{~N} N \mathrm{NaH}$. The small slab dissolver was replaced with a cylindrical dissolve $\bar{r}$ which will hold full scale APPR elements. In a shakedown run using a stainless steel prototype element, a dissolution rate of $6.5 \mathrm{~g} / \mathrm{min}$ at an aqua regia flow rate of $100 \mathrm{ml} / \mathrm{min}$ and a submergence of $3-1 / 2$ in. was obtained. 


\subsection{WASTE PROCESSING}

In the evaporation of "cold", simulated "25" waste, unneutralized solution gave a condensate $4.0 \mathrm{M}$ in $\mathrm{H}^{+}$, while neutralized solution gave

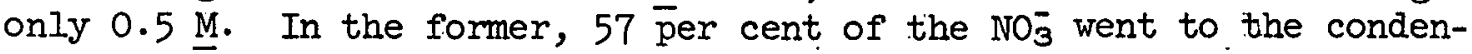
sate.

Filtrations of precipitated simulated "25", Darex, and SIR wastes were carried out using the "sand" filter. A report on the results is being written. 
Basic engineering research problems are being studied with the emphasis on problems peculiar to solvent extraction systems. These include development of steam pulsers and of methods of measuring interfacial areas and interfacial diffusional resistances. Studies of corrosion protection by transpirational flow and studies of thermal diffusion as a separations process are also being carried out.

\section{1:1: Transpirational Corrosion Protection - C.R. Simpkins, S. Ho. Jury,}

F. N. McLain

An improved experimental procedure was developed and applied in an attempt to confirm previously developed film theory (l) for transpirational corrosion protection. Previous studies $(1,2)$ have shown that a non-gasforming corrosion reaction of a simple mechanism was needed in order to obtain valid results.

In an attempt to find a system corrosive to nickel but giving no gaseous by-products, beaker corrosion studies considering cerric sulfate, cerric anmonium sulfate, and ferric chloride dissolved in $\mathrm{HCl}, \mathrm{H}_{2} \mathrm{SO}_{4}$, and $\mathrm{H}_{2} \mathrm{O}$ were made. Ferric chloride gave a corrosion rate of approximately 17 in./yr for a $40 \%$ by wt $\mathrm{FeCl}_{3} \cdot 6 \mathrm{H}_{2} \mathrm{O}$ aqueous solution. Dynamic corrosion rates were determined by varying bulk Reynold numbers between 4000 and 34,000 using a solid nickel tube and $20 \%$ by weight $\mathrm{FeCl}_{3} \cdot 6 \mathrm{H}_{2} \mathrm{O}$ as the corrosive agent. Corrosion rates were determined by analyzing the effluent stream for nickel by a colorimetric method and increased with Reynold's number to a value of approximately $130 \mathrm{in}$. yr at $\mathrm{NRe}=33,800$.

Corrosion rates were determined in a porous nickel tube protected by the transpirational injection of water. For conditions comparable to those in the nontranspirational runs, a minimum corrosion rate of approximately 1.5 in. a year was observed at a transpirational flow rate of 0.05 $\mathrm{cm}^{2}-\mathrm{sec}$

$\mathrm{cm}^{3}$. Application of theoretical considerations involving the kin-

etic rate equation predicted by stoichiometry [corrosion rate $=\mathrm{k}$ (Conc. $\left.\mathrm{FeCl}_{3}\right)^{2}$ ]. Indicates further revision of theory is necessary.

An attempt was made to fit the data from King's investigation of the corrosion of nickel by $\mathrm{HNO}_{3}-\mathrm{H}_{2} \mathrm{O}_{2}$ with transpiration. protection by utilizing a kinetic rate equation. Application of this theory to experimental

(1) King, G. J. and Jury, S. H., ORNL CF No. 57-9-32, Feb. 24, 1958.

(2) Patrick, S. B. and Bixler, H. J., M.I.T. Engineering Practice School EPS-X-338 KT-315, Dec.20, 1957. 
data indicates further revision of theory is necessary, probably because of gas formation at the reaction surface.

\subsection{Interfacial Area Measurements - J. F. Newman, C. V. Chester}

Equipment was installed and operated to measure interfacial areas by scintillation counting of a two-phase system consisting of a liquid organic scintillator and an alpha emitting aqueous phase. The originally proposed experimental procedure (see March UNOP Monthly Report, ORNL CF No. 58-3-71) was to use pulse height selection to select the depth of mixture counted. The signal strength from individual scintillations was too weak to permit elimination of the instrument noise background. This background was only a small fraction of the scintillations from the interfacial area in a small mixer, but was a large fraction of the signal for calibrations attempted with known interfacial areas. The increase of interfacial area with mixer speed was clearly shown. An accurate calibration has not yet been obtained because of the difficulty in obtaining a large known interfacial area. 


\subsection{DRUHM}

C. D: Scott

The direct reduction of uranium hexafluoride to uranium metal by use of sodium ( $\mathrm{UF}_{6}+6 \mathrm{Na}=\mathrm{U}+6 \mathrm{NaF}$ ) is being investigated. The study is currently concerned with the development of a reactor suitable for earrying out this reaction continuously.

\subsection{Experimental Work}

After the $\mathrm{UF}_{6}$ metering system used for run $\mathrm{D}-11$ was changed to allow higher flow rates and the sodium metering system had been completely cleaned out and reassembled, run D-12 was made. The reactor set-up was similar to that used in run D-10 (UNOP July Monthly, CF No. 58-7-126). This was a continuous reaction mun in which the $\mathrm{UF}_{6}$ vapor and sodium liquid were introduced to the reactor continuously. During the run there was a malfunction in the sodium metering system and the sodium flow rate was about 8 times. the stoichiometric amount (about a $10 \%$ excess is desirable). The UF 6 metering system operated satisfactorily at its maximum rate of $149 \mathrm{~g} / \mathrm{min}$ during the run. After $10 \mathrm{~min}$ the $\mathrm{mn}$ was terminated when it became evident that the $\mathrm{UF}_{6}$ entrance nozzle had been burned off.

Although the recorded inside reactor temperature exceeded $1200^{\circ} \mathrm{C}$, there was no evidence of massive uranium metal in the large excess of sodium present in the reactor. When the reactor was opened some uranium metal powder inside burned in the air. The UF, nozzle which was $1 / 4 \mathrm{in}$. Inconel tubing $2-1 / 2$ in. long was burned off to the top flange. This was disappointing. since it was hoped that high $\mathrm{UF}_{6}$ rates (above $100 \mathrm{~g} / \mathrm{min}$ ) would prevent nozzle burming or melting by the high gas velocity and the cooling effect of the UFG gas.

\subsection{Equipment Changes}

It has been decided to try a high melting point metal which has limited solubility in uranium metal for the $\mathrm{UF}_{6}$ nozzle in future tests. The first metal to be tried will be tungsten. It has a low solubility in uranium at operating temperatures and it is a high melting point metal. However, free energy considerations show that severe corrosion by the $\mathrm{UF}_{6}$ is likely. A i/4-in. nozzle made from tungsten is being fabricated. 


\title{
3.0 FLUOROX
}

\author{
C. D. Scott, G. K. Ellis
}

The Fluorox program is the engineering development of processes which produce $\mathrm{UF}_{6}$ without the use of elemental fluorine. The process of most interest at present is the oxidation of $\mathrm{UF}_{4}$ with oxygen, $2 \mathrm{UF}_{4}+\mathrm{O}_{2}=\mathrm{UO}_{2} \mathrm{~F}_{2}$ $+\mathrm{UF}_{6}$, with subsequent recycle of the $\mathrm{UO}_{2} \mathrm{~F}_{2}$.

\subsection{Fluidized Bed Development}

The $\mathrm{UF}_{4}$ oxidation process is being carried out in the 4-in. Fluorox fluidized bed reactor. Sized $\mathrm{UF}_{4}$ is continuously fed into a $\mathrm{UO}_{2} \mathrm{~F}_{2}$ bed which is fluidized in dry $\mathrm{O}_{2}$ at $800-850^{\circ} \mathrm{C}$. The $\mathrm{UF}_{6}$ which is produced is removed in the gas stream and subsequently recovered in cold traps.

Fluidization was lost in run FBR-20 because of a restriction in the lower part of the contactor caused either by scale from the contactor walis or by $\mathrm{UF}_{4}$ plugging the screen from underneath.

\subsubsection{Evaluation of Run FBR-19}

Complete experimental and analytical results from run FBR-19 have made it possible to evaluate the run in a manner similar to that used in pre-.. vious.runs. The over-all material balance for all entering and leaving streams was 101.7\% (Table 3.1 and Figure 3.1) with a difference of $392 \mathrm{~g}$ of material. This difference is within experimental error.

The $\mathrm{UF}_{6}$ balance was $97.0 \%$ (Figure 3.2) and the actual recovery of $\mathrm{UF}_{6}$ in the chemical traps and cold traps was $70.8 \%$ of theoretical. This recovery is about the same as that in FBR-18 which was $72.9 \%$.

As before, the largest loss of $\mathrm{UF}_{6}$ by a side reaction was to the water reaction where approximately $23 \%$ of the UF 6 formed reacted with the water which was introduced with the feed to the reactor. This represents a water content of about $1 \%$ in the feed. This high water content was due to the extensive handling of the feed in the feed preparation step.

The reaction rate constant determined for the operating temperature of $850^{\circ} \mathrm{C}$ during run FBR-19 was. $22.7 \mathrm{hr}^{-1}$ (Figure 3.3 ). This value compares favorably with extrapolated values from laboratory data.

Oxygen utilization for this run was $2.3 \%$ which was slightly higher than in run FBR-18 and which reflected the slightly higher feed rate used in run FBR-19.

These results show that in order to obtain higher product yields in the cold traps, the water content of the feed must be reduced prior to its entry to the reactor. The use of the filters in the reactor proper

$+\because 4 ?$ 
Table 3.1. Change in Amounts of Individual Compounds in Run FBR-19

\begin{tabular}{|c|c|c|c|}
\hline Compound & $\begin{array}{l}\text { Amount Entering } \\
\text { Reactor, } g\end{array}$ & $\begin{array}{l}\text { Amount Leaving } \\
\text { Reactor, } g\end{array}$ & $\begin{array}{c}\text { Change, } \\
\mathrm{g} \\
\end{array}$ \\
\hline $\mathrm{UF}_{4}$ & 15,520 . & 207 & $-15,313$ \\
\hline $\mathrm{UO}_{2} \mathrm{~F}_{2}$ & 6,949 & 17,123 & $+10,174$ \\
\hline $\mathrm{U}_{3} \mathrm{O}_{8}$ & 62 & 3 & -59 \\
\hline Metal Fluorides & 12 & 124 & +112 \\
\hline $\mathrm{UF}_{6}$ & 0 & 6,082 & $+6,082$ \\
\hline $\mathrm{H}_{2} \mathrm{O}$ & 202 & 0 & -202 \\
\hline $\mathrm{O}_{2}$ & $803^{*}$ & 0 & -803 \\
\hline $\mathrm{HF}$ & 0 & 401 & +401 \\
\hline Totals & 23,548 & 23,940 & +392 \\
\hline
\end{tabular}


$\mathrm{UF}_{4}-87 \mathrm{~g}$

$\mathrm{UO}_{2} \mathrm{~F}_{2}-5802 \mathrm{~g}$

$\mathrm{U}_{3} \mathrm{O}_{8}-3 \mathrm{~g}$

Metal Fluorides $-38 \mathrm{~g}$

$\mathrm{F}_{4}-48 \mathrm{~g}$

$\mathrm{UO}_{2} \mathrm{~F}_{2}-5928 \mathrm{~g}$

$\mathrm{U}_{3} \mathrm{O}_{8}-12 \mathrm{~g}$

Metal Fluorides $-12 \mathrm{~g}$

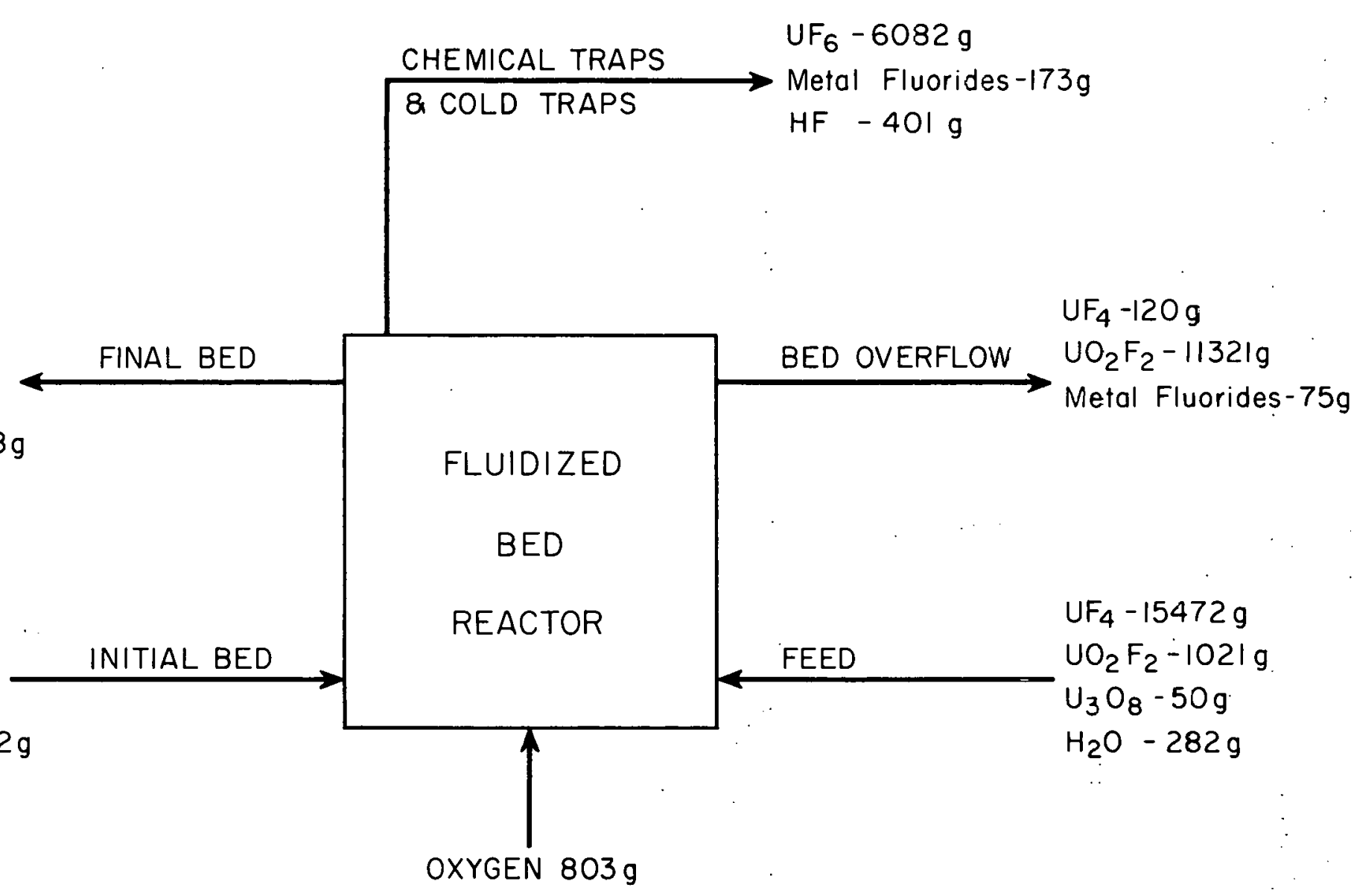

Fig. 3.I. Material Balance of the Constituents of Each Stream Fram Run FBR-19. 
UNCLASSIFIED

ORNL-LR-OWG 33490

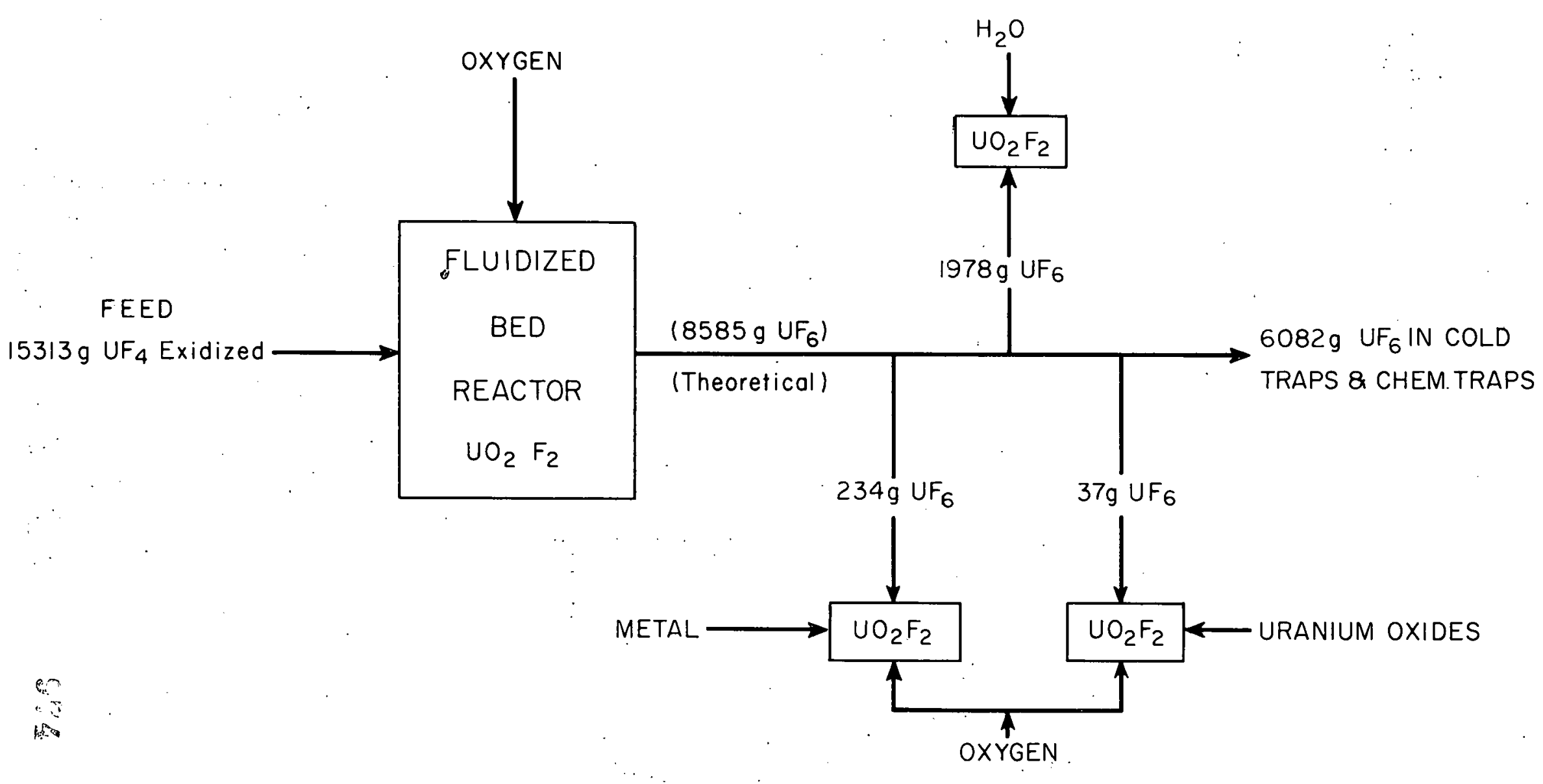

Fig. 3.2. Disposition of UF Formed in Run FBR-19. Total UF 6 accounted for $=8331 \mathrm{~g}$ or $97.0 \%$ of theoretical. Recovery of $U F_{6}$ in cold traps and chem. traps $=70.8 \%$ of theoretical. 


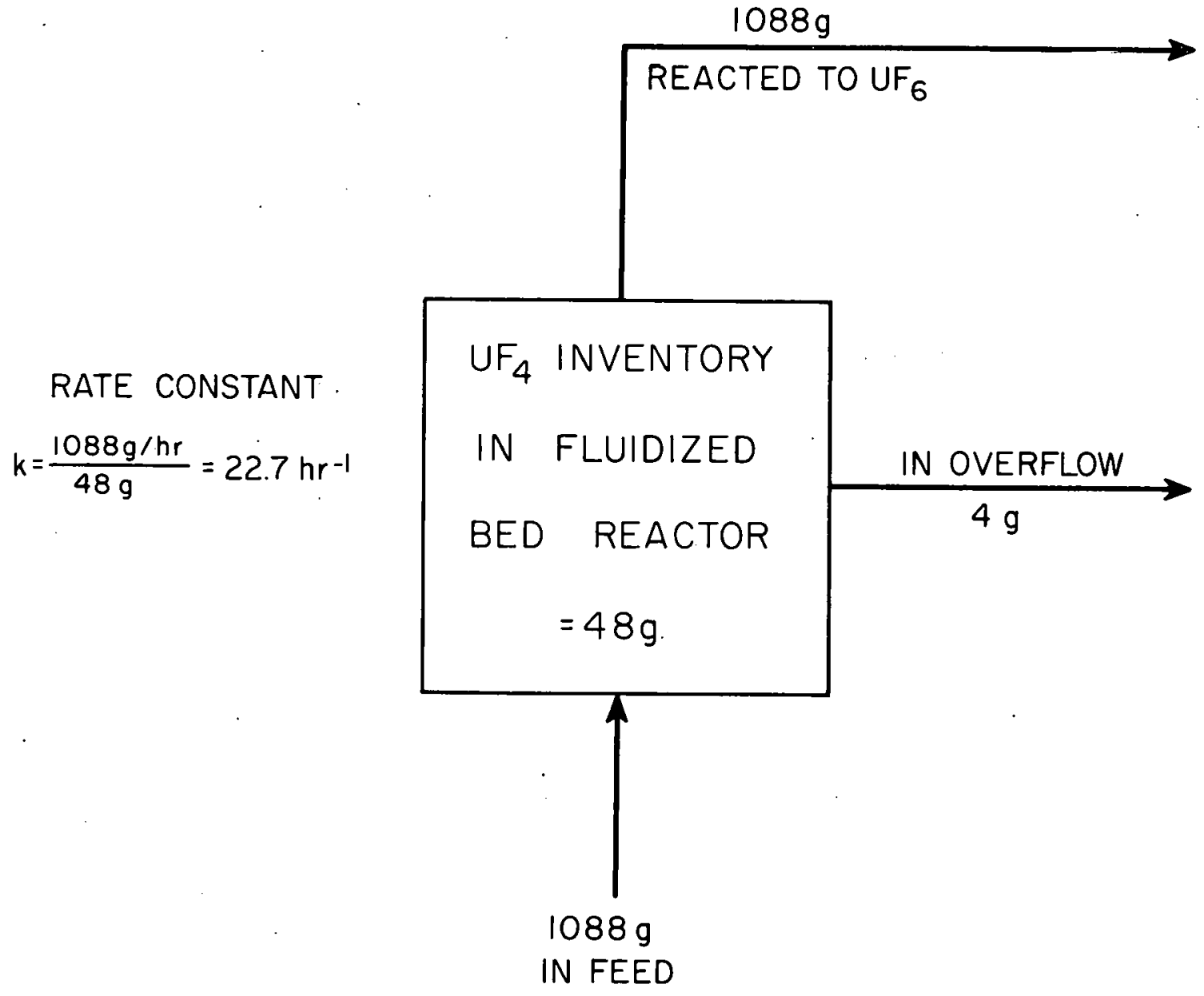

Fig. 3.3. $U_{4}$ Material Balance Across the Fluidized Bed Reactor in Run FBR-19. All flow rates are averages based on four hours of constant operation at essentially steady state. 
which eliminated $\mathrm{U}_{4} \mathrm{~F}_{17}$ formation has simplified operating techniques and increased product yield.

\subsubsection{Description of Run 20 and Reactor Modifications Required}

Fluidized bed reactor run FBR-20 was terminated after a 4-hr period of erratic operation. There was frequent loss of fluidization because of high pressure drops across the bed. A complete loss of fluidizing gas flow at a pressure drop in excess of 25 psi finally forced shutdown. The reactor was then dismantled and the bed removed for observation.

There was noted an almost total obstruction of the cross-sectional area for gas flow through the baffle unit located in the l-in. dia pipe through which the gas and $\mathrm{UF}_{4}$ entered the bottom of the reactor. The obstruction consisted of a mass of scale which apparently became loosened from the reactor walls during the severe conditions of thermal cycling during startup and shutdown of the unit. Several lumps of fused $\mathrm{UF}_{4}$ of a size sufficient to stop fluidization were observed within the bed, but these were probably formed after the bed lost its initial fluidization.

An alternate possibility is that the gas distribution screen could have become plugged from underneath with $\mathrm{UF}_{4}$ particles which fell around the perimeter of the screen between it and the contactor wall. This possibility will be eliminated in future runs by screening the entire flow area through.which UF 4 could fall (Figure 3.4). There will also be provision for pushing the baffle unit up from the l-in. dia section into the 4-in. dia section to eliminate or break up any accumulation of solids restricting gas flow in its usual position. The baffle unit will be attached to a 1/4-in. dia rod which will slide through the 3/8-in. tube housing shown in the drawing and will be sealed in place with a swedge-lock fitting. Another swedge-lock will seal the 3/8-in. tube housing to the bottom pipe cap so that the cap may be removed for clean-out of the section below the oxygen distribution screen.

A baffle will be placed below the sintered nickel filters to function both $8 s$ an impingement separator to aid in de-entrainment of solids from the off-gas stream and to secure operation of the filters at a lower temperature. This alteration will prevent the high temperature $\left(800-850^{\circ} \mathrm{C}\right)$ fluidized bed from seeing the filters and will therefore cut down the heat transfer to the filters by radiation.

\subsubsection{FBR Feed Preparation}

Minor modifications are being made to the $\mathrm{UF}_{4}$ feed preparation facility for the purpose of preparing a quantity of feed which will be sufficient for process operation during the remainder of the Fluorox program.

There will be provision made for keeping the Trommel screen from becoming blinded; a nylon brush will be installed to continually brush the screen. Also, there will be fabricated a gravity feed unit to feed Chilsonator compacted $\mathrm{UF}_{4}$ to the rolling mill. 


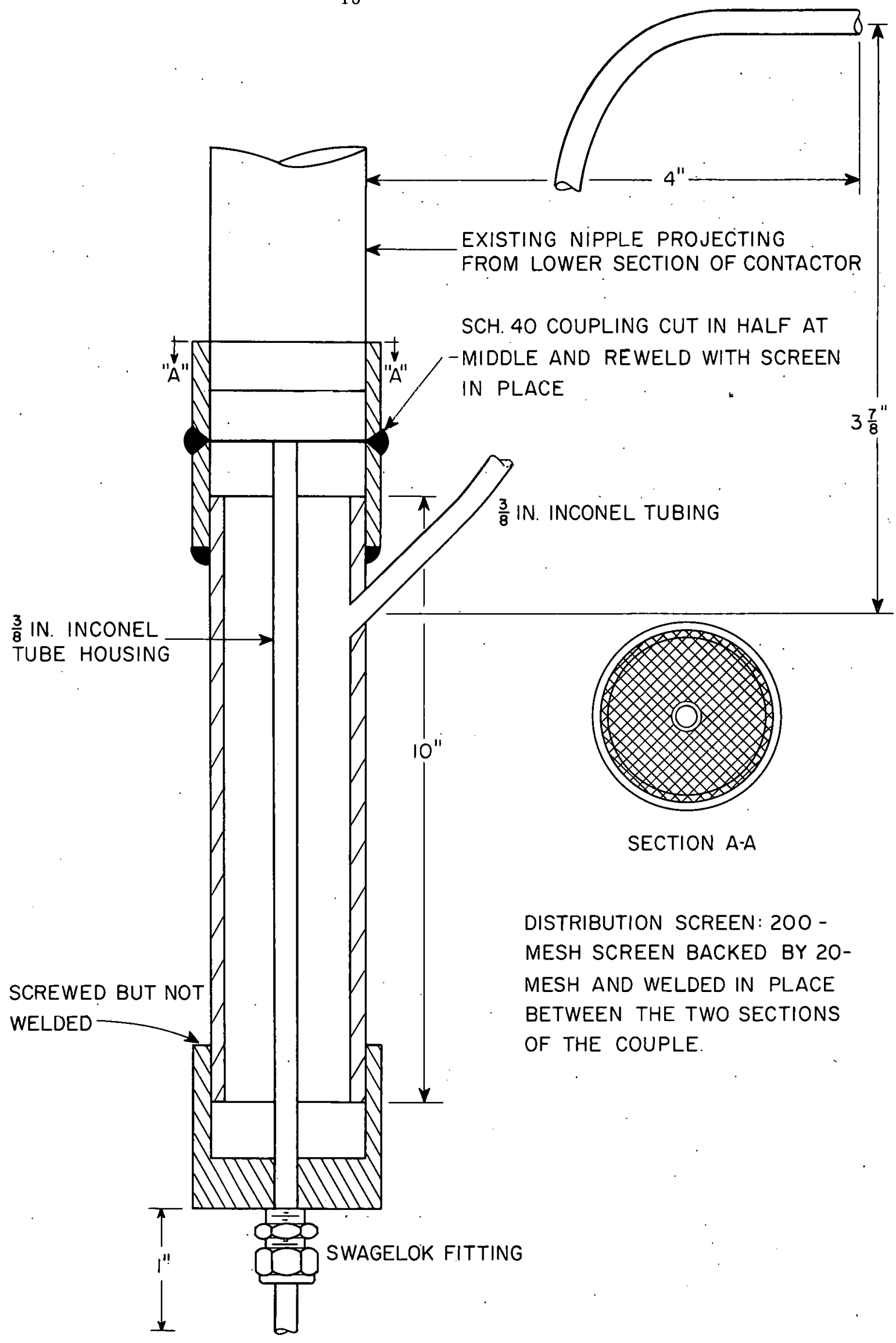




\section{$-17-$}

4.0 HR FUEL AND BLANKET PREPARATION AND PROCESSING

P. A. Haas

This program includes the development of processes and equipment for preparation and reprocessing of aqueous homogeneous reactor fuel and blanket fluids.

The present emphasis is on development of direct de-nitration methods for producing thorium and/or uranium oxide slurries and on assistance studies as required by the HRT-CPP and the PAR loop programs.

4.I Flame Calcination - C. C. Haws, Jr., V. L. Fowler

Repeated attempts to adapt the slurry feed torch to direct de-nitration of thorium-uranium nitrates were unsuccessful. A new torch was operated in which the fuel gases and the nitrate-bearing alcohol are injected separately into the combustion chamber. Temperatures obtained with the new design are adequate and particle size distribution was improved.

Exploratory quantities of mixed nitrates had been fired in the existing carbureting torch developed for slurry feeds in the early phases of this work. Three firings yielded small quantities of particulates in the desired size range. The existing torch was designed to attain the highest possible temperatures with the feed system used. Repeated attempts were made to adapt the existing equipment to the new nitrate feed. Violent flashbacks and damage to the fuel gas system limited flame de-nitration operation to short periods with this torch. The point at which the alcohol-nitrate stream entered the mixer-heating section was moved by steps from the rear of this section (its original location for the slurry calcining) to the exit orifice. No arrangement was successful in which the gases and the alcohol nitrate solution were pre-mixed before entry into the combustion chamber.

A crude test involving separate injection of the alcohol-nitrate and the fuel gases was successful, therefore, a torch was built incorporating this feature (see Figure 4.1). Reflector temperatures above $1600^{\circ} \mathrm{C}$ are easily obtained with this improved design. These temperature levels are believed adequate for complete flame de-nitration. An improved size distribution of 1.5 micron mean diameter and 85 wt per cent below 5 microns was obtained in three subsequent firings with the new torch (Figure 4.2). For reference, previous firings produced an average particle size of 2 microns with $80 \%$ of the particles being less than 10 microns in size. The three latest firings provided approximately 1 lb of product, from which a classified (<5 micron) sample was submitted for toroid testing. Surface area of the later material however is higher (5.8 vs. $4.6 \mathrm{sq}$. meters per gram) than the first product. 


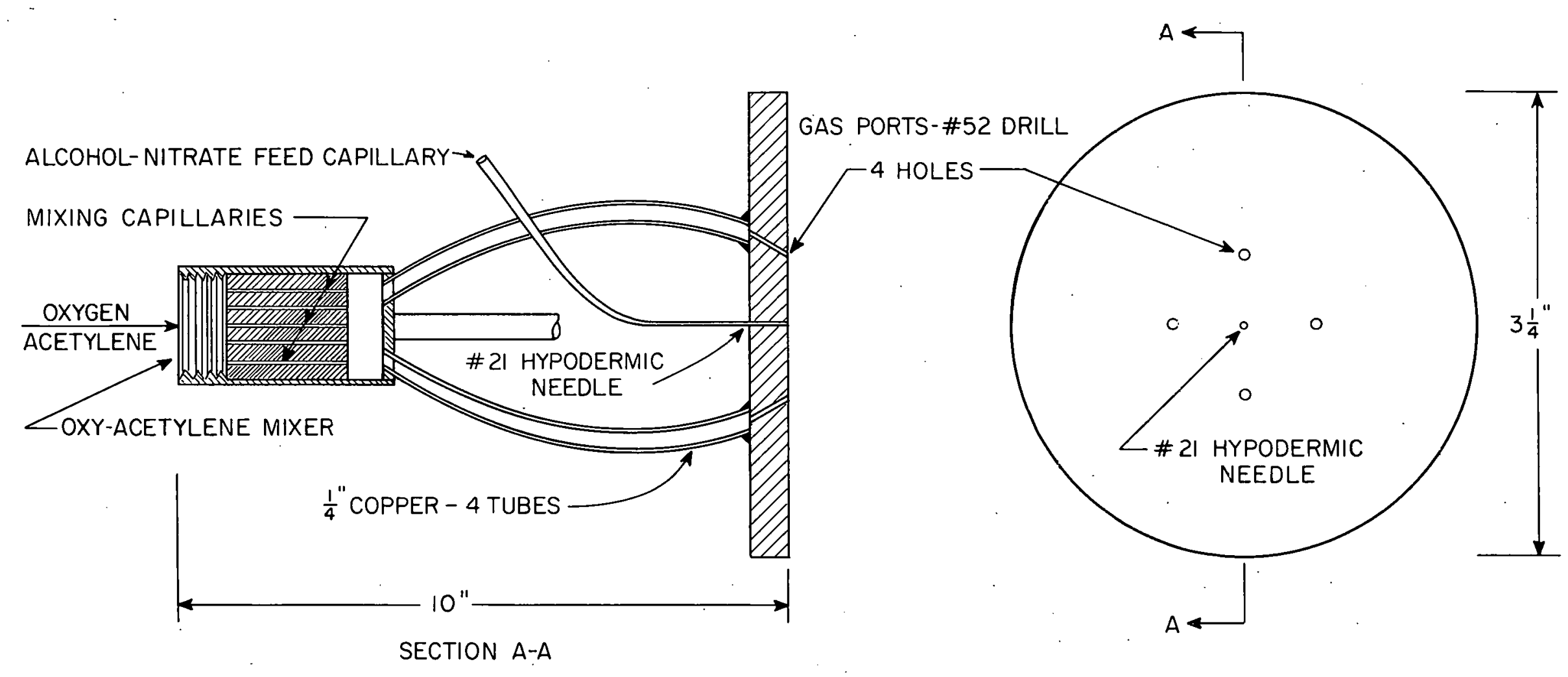

Fig. 4.I. Flame Calcination Experiments-Direct Denitration Torch. 


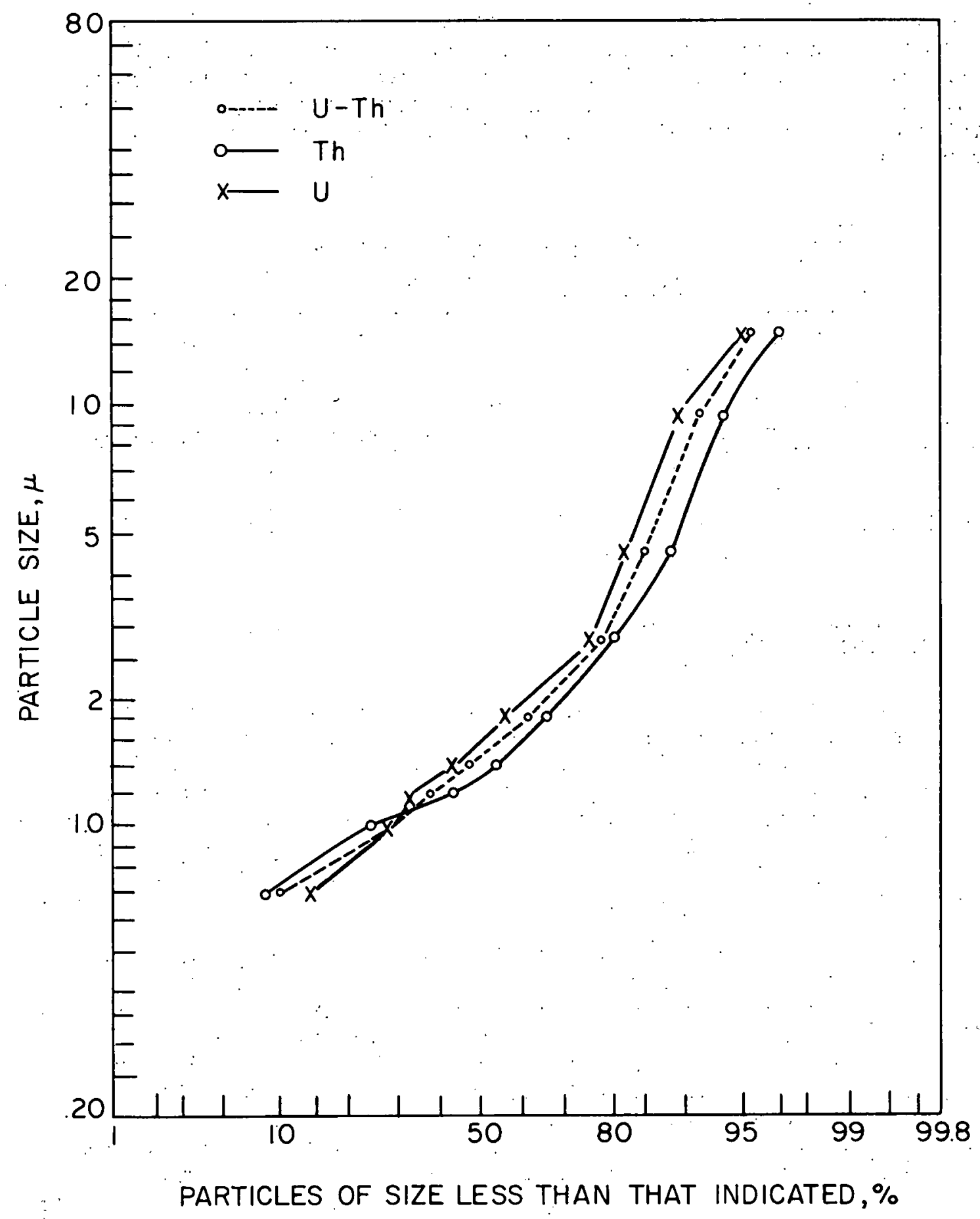

Fig. 4.2. Run No. 35. Flame Calcination Experiments.TNTUNH Denitration. Results of product particle size measurements. 
Corrosion results from toroid tests are available for the products of runs 15 and 16 (see Table 4.1). These two runs were the first of the $\mathrm{ThO}_{2}$ in $\mathrm{CH}_{3} \mathrm{OH}$ slurry feed series to use the graphite reflected flame. These corrosjon rates show the flame fired material to be equal to the best material produced to date from furnace firings. Degradation (change in average particle size) formed in run 15 is near the average for furnace fired material, while degradation for the higher fired product of run 16 may not be detectable.

Table 4.1. Flame Calcining Experiments Toroid Corrosion Results

\begin{tabular}{|c|c|c|c|c|c|c|c|}
\hline \multirow{3}{*}{$\begin{array}{l}\text { Run } \\
\text { No. }\end{array}$} & \multirow{3}{*}{$\begin{array}{l}\text { Calcining } \\
\text { Temp., } \\
\text { oC }\end{array}$} & \multirow{2}{*}{\multicolumn{2}{|c|}{$\begin{array}{c}\text { Average Particle } \\
\text { Sizes, } \\
\text { micron } \\
\end{array}$}} & \multirow{3}{*}{$\begin{array}{c}\text { Stainless } \\
\text { Steel }\end{array}$} & \multicolumn{3}{|c|}{$\begin{array}{c}\text { Corrosion Rates, } \\
\text { (mpy) }\end{array}$} \\
\hline & & & & & \multirow[b]{2}{*}{ Titanium } & \multirow{2}{*}{$\begin{array}{l}\text { Mild } \\
\text { Steel }\end{array}$} & \multirow[b]{2}{*}{ Zircaloy } \\
\hline & & Pre-Run & Post-Run & & & & \\
\hline 15 & 1200 & 1.2 & 0.8 & 2.6 & 1.4 & 22 & 0.9 \\
\hline 16 & 1600 & 1.2 & 1.0 & 2.8 & 0.9 & 7.8 & wt gain \\
\hline
\end{tabular}

4.2 Fluidized Bed De-nitration - S. D. Clinton, H. I. List, R. D. Arthur, F. N. McLain

Feed system alterations were required before $\mathrm{Th}\left(\mathrm{NO}_{3}\right)_{4}$ solution could be sprayed into the fluidized $\mathrm{ThO}_{2}$ bed. Water under an air pressure of 30 psig was sprayed into the $\mathrm{ThO}_{2}$ bed at $600^{\circ} \mathrm{C}$ with no apparent difficulties; but the spray nozzle became plugged when $\mathrm{Th}\left(\mathrm{NO}_{3}\right)_{4}$ was introduced into the liquid feed. A water-cooled spray nozzle was installed. The $\mathrm{Th}\left(\mathrm{NO}_{3}\right)_{4}$ solution still plugged the nozzle until the spray nozzle was altered and a positive displacement type pump was connected directly to the liquid feed line.

Approximately 6 liters of $1.5 \mathrm{M} \mathrm{Th}\left(\mathrm{NO}_{3}\right)_{4}$ solution was sprayed into the bed at $600^{\circ} \mathrm{C}$ at a liquid feed rate of $7.5 \mathrm{ml}$ per min. Pressure measurements in the oxide bed during the major part of the run and after shutdown indicated that the bed was not completely fluidized. About $13 \%$ of the $\mathrm{ThO}_{2}$ had formed a strongly agglomerated cake which prevented proper fluidization of the $\mathrm{ThO}_{2}$ particles. After the addition of the first 2 liters of $1.5 \mathrm{M} \mathrm{Th}\left(\mathrm{NO}_{3}\right)_{4}$ solution, about $100 \mathrm{cc}$ of $100-1000$ micron spheres were found in the product tank. Examination indicated that these spheres were agglomerates with perhaps some cementing by de-nitration product. 
$4.3 \frac{\text { Hydroclone Preparation of Purge Streams - P. A. Haas, J. W. Snider, }}{\text { R. C. Early }}$

A two-stage cascade of a $0.4 \mathrm{in}$. dia and a $0.25 \mathrm{in}$. dia hydroclone was tested for clarification of slurries of $240-400 \mathrm{~g} \mathrm{Tho} / \mathrm{kg} \mathrm{H} \mathrm{H}_{2} \mathrm{O}$. The feed to last stage overflow concentration ratios were between 6 and 61 (Table 4.2). These values are larger than those for otherwise similar conditions with a three-stage cascade of a 0.8 , a 0.4 , and a 0.25 in. dia hydroclone (see Unit Operations Section Monthly Report for August, CF No. 58-8-59). This indicates either that the 0.8 in. dia hydroclone is not an effective initial stage or that dividing 65 to $75 \mathrm{ft}$ of pressure drop between three hydroclones is less effective than dividing it between two hydroclones.

Use of cylindrical hydroclones with induced underflow receivers was tested for slurry collection. Preliminary results indicate that a 0.4 in. dia, 4-3/4 in. long cylindrical hydroclone gives results comparable to those for 0.4 in. dia conical hydroclones. Although the efficiency appears slightly reduced, the cylindrical design should reduce plugging of the underflow port during operation with slurries that tend to cake.

\subsection{Precipitation Studies - W. M. Woods, D. A. McWhirter}

Mixed thorium-uranium oxides were prepared by decomposition of precipitates from the addition of $\mathrm{NH}_{4} \mathrm{OH}$ to nitrate salt solutions. Neither amine complexing agents nor variations in precipitation and digestion procedures gave any products which merited further study. Preparation of chloride free $\mathrm{U}\left(\mathrm{C}_{2} \mathrm{O}_{4}\right)_{2}$ for co-precipitation with $\mathrm{Th}\left(\mathrm{C}_{2} \mathrm{O}_{4}\right)_{2}$ was found to be a tedious, time consuming process due to very slow filtration rates and the amount of washing required to remove chlorides. 
Table 4.2. Preparation of Purge Water

Two Hydroclone Cascade Test

$\mathrm{ThO}_{2}$ : $650^{\circ} \mathrm{C}$ calcined (DT-7) with indicated 2.3 micron mean diameter

Conditions: 65-70 feet of fluid pressure drop, room temperature

\begin{tabular}{|c|c|c|c|c|c|c|c|c|}
\hline \multirow{2}{*}{$\begin{array}{c}\text { Feed } \\
\text { Sample, } \\
\text { g } \mathrm{ThO}_{2} / \mathrm{kg} \mathrm{H}_{2} \mathrm{O}\end{array}$} & \multicolumn{3}{|c|}{ First $(0.4$ in.) Hydroclone } & \multicolumn{4}{|c|}{ Second ( 0.25 in.) Hydroclone } & \multirow[b]{2}{*}{$\frac{\mathrm{C}_{\text {Feed }}}{\mathrm{C}_{\text {Product }}}$} \\
\hline & $\begin{array}{l}\Delta P \\
\mathrm{ft}\end{array}$ & $B / F$ & $\begin{array}{l}\text { Underflow, } \\
\mathrm{g} \mathrm{ThO}_{2} / \mathrm{kg} \mathrm{H}_{2} \mathrm{O}\end{array}$ & $\begin{array}{l}\Delta P, \\
f t\end{array}$ & $\frac{B}{F}$ & 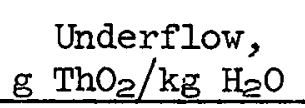 & $\begin{array}{c}\text { Overflow, } \\
\mathrm{g} \mathrm{ThO}_{2} / \mathrm{kg} \mathrm{H} \mathrm{H}_{2} \mathrm{O}\end{array}$ & \\
\hline 239 & 35 & .41 & 515 & 30 & .48 & 101 & 3.9 & 61 \\
\hline 320 & 35 & .60 & 529 & 30 & .69 & 64 & 6.9 & 46 \\
\hline 393 & 35 & .58 & 608 & 30 & .077 & 426 & 65.3 & 6 \\
\hline 355 & 60 & .72 & 465 & 6 & .52 & 128 & 7.3 & 49 \\
\hline 342 & 60 & .73 & 445 & 6 & .17 & 320 & 15.9 . & 22 \\
\hline 346 & 60 & .70 & 452 & 6 & .76 & 86 & 9.1 & 38 \\
\hline $286 *$ & 40 & .47 & 506 & 9 & .38 & 226 & 14.8 & $19^{*}$ \\
\hline 341 & 20 & .33 & 731 & 50 & .54 & 271 & 13.8 & 25 \\
\hline 362 & 20 & .34 & 758 & 50 & .79 & 197 & 13.9 & 26 \\
\hline
\end{tabular}

*Total pressure drop was $40+9=49 \mathrm{ft}$. 


\subsection{ION EXCHANGE}

J. S. Watson

\subsection{Mechanism and Kinetic Studies}

In order to make rational predictions of the operating characteristics of uranium anion exchange contactors, an understanding of the mechanism and kinetics of the exchange is necessary. Toward this objective an effort is being made to determine the equilibrium sorption isotherms and rates of sorption of uranium on Dowex $2 \mathrm{lK}$.

Several runs have been made to determine the resin uranium loading in equilibrium with $0.005 \mathrm{M}$ uranyl sulfate solutions containing different total sulfate concentrations. The purpose of these runs was to determine if maximum uranium loading. occurred from solutions with sulfate concentrations near $0.04 \mathrm{M}$. It has been shown $(1,2)$ that if a maximum loading does occur near this concentration, two sorption mechanisms may be proposed, and loading data in this region may permit much needed recalculation of the $\mathrm{UO}^{+}{ }^{+}-\mathrm{SO} \overline{\overline{4}}$ association constants.

In these equilibrium studies, the solutions were all maintained $0.020 \mathrm{M}$ in sulfuric acid to maintain the $\mathrm{pH}$ below 2 . This was necessary to avoid hydrolysis of the $\mathrm{UO}_{2}^{++}$ion to $\mathrm{U}_{2} \mathrm{O}_{5}^{++}$. The total sulfate concentration in the various solutions was controlled by adding the required amount of sodium sulfate. Approximately 4 liters of solution and 3 grams of resin were used in each run. The solution was allowed to flow very slowly through a glass filter funnel containing the resin for from 24 to $48 \mathrm{hr}$ (Figure 5.1). When flow stopped for any reason, solution was maintained in the resin tube by a small jack-leg. In the initial runs, the uranium concentration in the solution leaving the resin was recorded by a flow colorimeter. This instrument indicated that 4 liters was an adequate volume to approach equilibrium sorption. After loading, the resin was centrifuged for. 30 min to remove solution clinging to the beads. Then the resin was eluted with 1 liter of $1 \mathrm{~N}$ sodium chloride, washed with water, dried for 3 days at $55^{\circ} \mathrm{C}$, and weighed. The eluate was then analyzed for uranium, sulfate, and total hydrogen ion.

The analyses for total hydrogen ion gave a measure of the resin sites occupied by bisulfate ions. Uranium is not believed to be sorbed on bisulfate occupied sites, and these account for very roughly 10 per cent of the total sites with the conditions belng studied.

The data available thus far are shown in Figure 5.2. Although the data are not yet complete, no maximum in the sorption curve is indicated very near a sulfate concentration of $0.04 \mathrm{M}$. This could mean that the proposed sorption mechanisms are incorrect, or it could mean that the values assumed for the $\mathrm{UO}_{2}^{+}-\mathrm{SO}^{=}$association constants were incorrect. The latter reason appears very likely since the authors who determined these constants 
ORNL-LR-DWG 33495

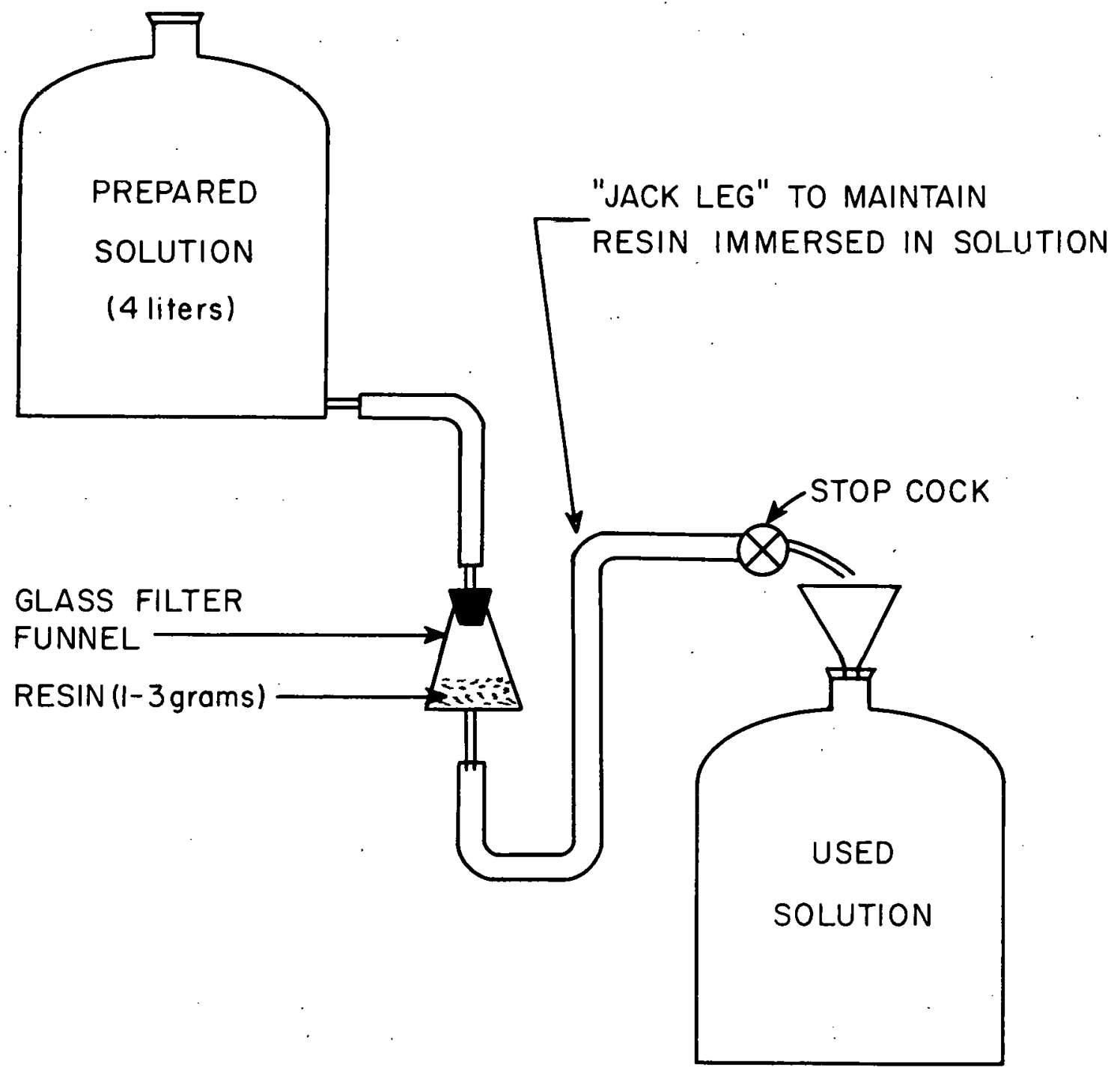

Fig. 5.I Diagram of Apparatus for Ion Exchange Equilibra Studies. 
UNCLASSIFIED

ORNL-LR-DWG 33496

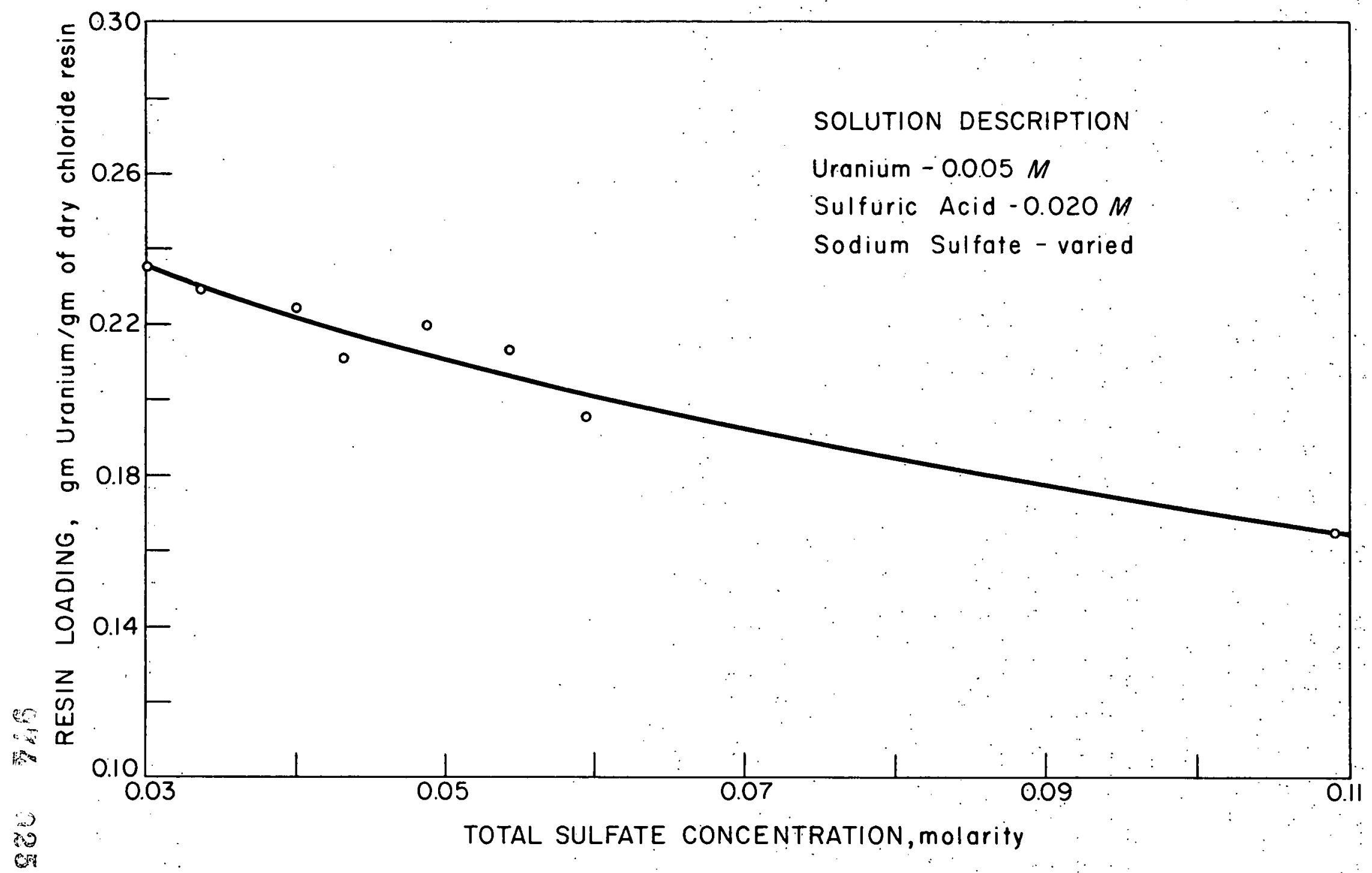

Fig. 5.2 Uranium Loading on Dowex $21 \mathrm{~K}$ as a Function of Sulfate Concentration in Solution. 
did not claim a high accuracy in their numbers. Using the extreme values of their uncertainty limits, one can see that the maximum sorption could occur at a much lower sulfate concentration. However, with the uranium and sulfuric acid concentrations currently used, it would be impossible to have solutions with total sulfate concentrations less than $0.025 \mathrm{M}$ since the uranyl sulfate and acid contribute that much sulfate.

Some consideration has been given to ways of studying loading at lower sulfate concentrations. Any series of runs for this purpose must employ solutions containing a constant total uranium concentration and sulfuric acid concentration, but with varied additions of sodium sulfate. The minimum total sulfate concentration obtainable in a series of runs could be made slightly lower by using a lower total uranium concentration and/or a lower sulfuric acid concentration. It would probably be possible to use a total uranium concentration as low as $0.0005 \mathrm{M}$ and a total sulfuric acid concentration of $0.01-0.015 \mathrm{M}$. However, it should be noted that with very low sulfuric acid concentrations there would be a maximum total sulfate concentration which could be studied because additions of sodium sulfate to these solutions result in a higher $\mathrm{pH}$ (Figure 5.3). If the $\mathrm{pH}$ became much greater than 2.0 hydrolysis of the uranyl ion would occur.

One other solution would be to substitute hydrochloric acid for some of the sulfuric acid. However, in this case many of the resin sites would be filled with chloride rather than with sulfate and uranium ions. A correction may be obtained by eluting with sodium nitrate and analyzing the eluate for chloride as well as for uranium and sulfate. Here the assumption would be made that only the sulfate sites are active for uranium sorption. However, the uranium loading may prove much too low to give any accurate results.

(1) Unit Operations Section Monthly Report for August, CF No. 58-8-59.

(2) Jury, S. H., "Uranyl Sulfate-Dowex 21K Anion Exchange", manuscript in preparation. 
UNCLASSIFIED

ORNL-LR-DWG 33497

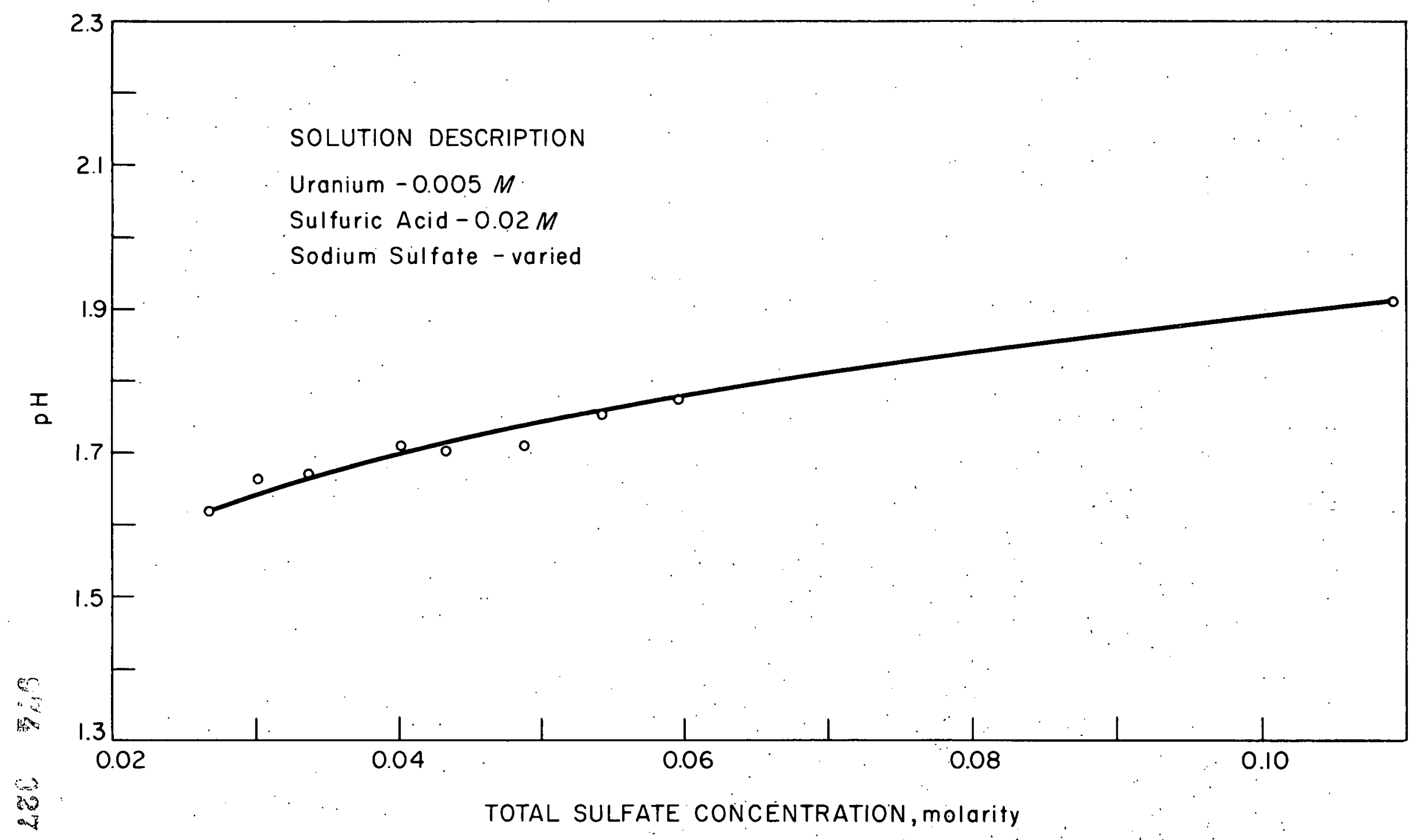

Fig. 5.3. $\mathrm{pH}$ of Uranyl Sulfate Solutions as a Function of Total Sulfate Concentration. 


\subsection{POWER REACTOR FUEL REPROCESSING}

C. D. Watson

\subsection{Darex - F. G. Kitts, B. C. Finney, F. R. Rogers, J. Beams}

The purpose of the Darex process is to convert stainless steel-U and stainless steel- $\mathrm{UO}_{2}$ fuel elements into chloride-free nitrate solutions suitable for processing in existing solvent extraction equipment. Chloride must be added to effect dissolution of stainless steel in $\mathrm{HNO}_{3}$ and then removed to avoid corrosion of feed adjustment, solvent extraction, and waste handling equipment. In the present concept of Darex, dissolution and chlorlde stripping are accomplished in a loop system; $\mathrm{HNO}_{3}$ is removed from the highly acidic stripped product and the concentrated solution containing metallic salts is adjusted, by dilution, providing feed for solvent extraction. Continuing investigation will study the effect of system operating conditions on dissolution rates, chloride removal and recovery, offgas losses, $\mathrm{HNO}_{3}$ recovery and feed adjustment when dissolving fuels with various stainless steel/U ratios.

A $13-1 / 2 \mathrm{hr}$ run (run 72 ) was made using the complete integrated loop (Figure 6.1). The $\mathrm{HNO}_{3}$ boiler was operated on level control, the feed adjustment tank overhead was continuously and automatically adjusted by the addition of $22.5 \mathrm{~N} \mathrm{HNO}_{3}$, and the condenser product was continuously adjusted to furnish aqua regia feed to the dissolver. The run was interrupted 3 times because of excessive hold-up in the stripping column. It was later found that the interior of the column was badly coated with a siliceous material which resulted in a decreased throughput. The fuel elements used were 5/16" square $\times 3-3 / 4 "$ long rectangular laminates that had been fabricated from prototype APPR fuel plates. The relatively high silica content (2\%) of the $302 \mathrm{~B}$ stainless steels resulted in a rapid coating of the exposed surfaces in the stripping column. It appears that future runs using APPR fuel elements and the present 4-in. dia bubble cap stripping column will be limited to between 8 and $16 \mathrm{hr}$. It has been found that the coating can easily be removed by flushing the column with hot $2 \underline{\mathrm{N}} \mathrm{NaOH}$.

The material balance for run 72 is presented in Figure 6.1. Since the run was interrupted a number of times, steady state operation could not be obtained and the material balance is presented for qualitative purposes only. The automatic valve in the acid line to the feed adjustment tank overhead surge tank would not fully close and as a consequence the tank contents were too high in $\mathrm{HNO}_{3}, 16.4 \mathrm{~N}$ rather than the desired $15.8 \mathrm{~N}$. This in turn resulted in excessive $\mathrm{HIO}_{3}$ in the stripping column overhead and therefore it was not necessary to add any make-up $\mathrm{HNO}_{3}$ to the condenser product adjustment tank.

The small slab dissolver was replaced with a cylindrical dissolver, 4-l/2 in. I.D. $\times 7$ in. long. This dissolver will be used for dissolution studies of full size (2-7/8 in. square $x 22$ in. long) APPR fuel elements. 


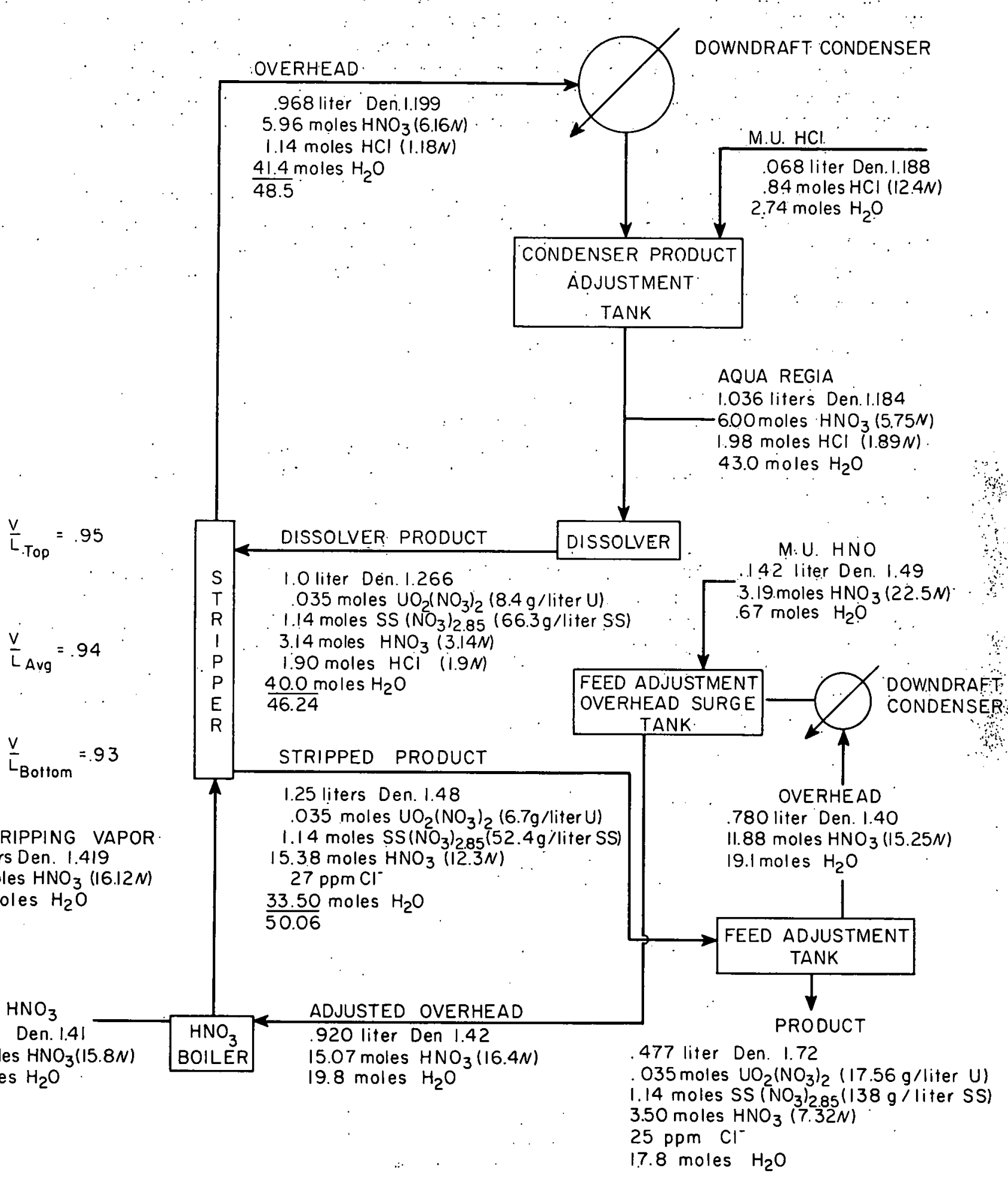

Fig. 6.I. Moterial Balance For Darex Run 72. Basis: I liter of dissolver product. 
A.5-1/2-hr shakedown run (run 73) using a full size stainless steel prototype APPR fuel element was made. The analytical results from this run are not yet available, but the dissolution rate as determined by fuel element weight loss was $6.5 \mathrm{~g} / \mathrm{min}$ at an aqua regia flow rate of $100 \mathrm{ml} / \mathrm{min}$. The dissolver is equipped with a jack-leg so that the static submergence is approximately $3-1 / 2$ in. There was only a minor amount of foaming in the dissolver during the run.

The installation of a l-in. glass dissolver with auxiliary equipment for dissolution studies of plate type fuel elements has been completed. It will allow the study of higher $\mathrm{F} / \mathrm{S}$ ratios than presently possible with the Darex loop equipment. It will also be determined if the dissolver liquid level can be regulated with an airlift.

\subsection{Zircex - J. J. Perona, G. B. Dinsmore}

The Zircex process utilizes anhydrous $\mathrm{HCl}$ as a reagent for processing zirconium-containing fuels, with the separation of the volatile $7 \mathrm{rCl} \mathrm{l}_{4}$ from the relatively nonvolatile $\mathrm{UCl}_{3}$. Recovery of the $\mathrm{UCl}_{3}$ can be effected by the fluoride volatility process or by solvent extraction in the aqueous nitrate system.

Mass spectrographic analyses of $\mathrm{HCl}$ from Matheson and Frontier Chemical Company revealed the principal impurities to be $\mathrm{CO}_{2}$ in the Matheson gas and air in the Frontier gas (Table 6.1). In the aqueous recovery method, excessive uranium loss from the formation of an insoluble uranium-containing solid solution is thought to be caused by oxygen-containing impurities in the $\mathrm{HCl}$. Total free and combined $\mathrm{O}_{2}$ was $0.78 \%$ in Matheson reagent and $0.65 \%$ in the Frontier reagent... All Zircex data reported to date have been obtained with the Matheson reagent.

Table 6.1. Hydrogen Chloride Analyses

\begin{tabular}{lcc}
\hline & $\begin{array}{c}\text { Matheson, } \\
\text { mol \% }\end{array}$ & $\begin{array}{c}\text { Frontier, } \\
\text { mol\% }\end{array}$ \\
\hline $\mathrm{HCl}$ & 98.97 & 95.59 \\
$\mathrm{~N}_{2}$ & 0.14 & 3.62 \\
$\mathrm{O}_{2}$ & 0.002 & 0.49 \\
$\mathrm{~A}$ & - & 0.04 \\
$\mathrm{CO}_{2}$ & 0.67 & 0.06 \\
$\mathrm{H}_{2} \mathrm{O}^{*}$ & 0.22 & 0.20 \\
\hline \multicolumn{3}{c}{} \\
\hline
\end{tabular}

*By Karl Fischer titration. 
Using the Frontier reagent, a $5.45 \mathrm{~kg}$ section of unirradiated STR subassembly (gross composition $0.8 \% \mathrm{U}-99.2 \%$ Zircaloy-2) was reacted to completion with an average reaction rate of $2.3 \mathrm{mg} /\left(\mathrm{cm}^{2}-\mathrm{min}\right)$. The amount of uranium insoluble in $10 \mathrm{M} \mathrm{HNO}_{3}$ was $1.1 \%$, compared to $1.8 \%$ and $3.4 \%$ in experiments with Matheson $\mathrm{H} \overline{\mathrm{C}} \mathrm{I}$ at approximately the same average reaction rate, temperature profile and $\mathrm{HCl}$ utilization efficiency. From this experiment, $\mathrm{CO}_{2}$ appears to be a slightly more harmful impurity, mole for mole, than $\mathrm{O}_{2}$, possibly due to the contribution of $\mathrm{ZrC}$ and $\mathrm{UC}$ to the insoluble complex. If the aqueous recovery method were to be applied to the premium power fuels, either reagent would have to be purified to prevent excessive uranium losses.

\subsection{Solvent Extraction Studies - R. J. McNamee, F. L. Rogers}

The Hanford Atomic Products Operation is planning to reprocess spent power reactor fuel with a modified Redox flowsheet. Since the flowsheet will be different from the present aluminum feed, acid-deficient Redox flowsheet, they have requested the Chemical Technology Division to determine column capacities, system stability, extraction efficiencies, and fission product decontamination for several proposed flowsheets. The flowsheet will be studied without activity in a 2-in. glass packed column by the Unit Operations Section, and the pilot plant will make several hot runs in shielded equipment.

A major problem is that the Redox process gives better decontamination when the acidity is less than that necessary to prevent stainless steel solutions from precipitating.

A trip was made to Richland, Washington to discuss the problem and proposed runs with A. M. Platt and associates (see ORNL CF No. 58-10-73)。

The 2-in. glass column in Building 3503 has been packed with $1 / 4$ " $\times 3 / 8$ " Raschig rings, and the electrical equipment made explosion proof in preparation for these runs. A dissolution method for stainless steel fuels has not been fixed, which further complicates the problem. Most of the effort will be placed on evaluating Darex and Niflex ( $\mathrm{HNO}_{3}-\mathrm{HF}$ ) type dissoIution feeds.

\subsection{Reprocessing of Irradiated PWR Blanket Fuel Elements - G. A. West, J. C. Rose, T. A. Gens (Chemical Development)}

The study of decladding and core dissolution of PWR blanket elements was continued to evaluate the flowsheet using $6 \mathrm{M} \mathrm{NH}_{4} \mathrm{~F}-1 \mathrm{M} \mathrm{NH}_{4} \mathrm{NO}_{3}$ to declad, followed with $10 \mathrm{M} \mathrm{HNO}_{3}$ for core dissolution. Protōtype PWR blanket pins, autoclaved to produce an oxide coating $\left(\mathrm{ZrO}_{2}\right)$, are now being used in the shakedown runs in a hot cell, Building 4507. 
In laboratory tests, the dissolution time required to penetrate the $30 \mathrm{mil}$ wall of the oxide coated pins varied from 2 to $4 \mathrm{hr}$ except for one mun when $17 \mathrm{hr}$ was required. Since the end caps were only partially dissolved in this time, the flowsheet was changed to allow $8 \mathrm{hr}$ decladding. time. This allows more $\mathrm{UF}_{4}$ precipitate to form with the $\mathrm{ZrO}_{2}$ solids. A conical-bottomed glass vessel was installed to separate the undissolved solids and precipitates by settling, and to allow visual observation of the precipitates. The zirconium oxide and $\mathrm{UF}_{4}$ precipitates which collected during dejacketing were easily separated and collected for analysis. Ammonium fluorozirconate was allowed to crystallize overnight in the decladding solution containing excess ammonium fluoride; it was easily redissolved by adding $\mathrm{H}_{2} \mathrm{O}$ and the resulting solution was easily transferred from the container.

Changes were required in the remotely operated sample transfer train which was designed for permanent installation. The startup of hot runs is scheduled for September 22, 1958. This date is dependent upon the completion of alterations and operability of the sample transfer train.

\subsection{Prototype Fuels - G. A. West, J. C. Rose}

A total of 26. prototype Consolidated Edison fuel jackets (304 SS) with end caps were fabricated. These jackets are to be loaded with pellets containing $4.5 \% \mathrm{UO}_{2}(93 \% \mathrm{U}-235)$ and $95.5 \% \mathrm{ThO}_{2}$. The fuel pins, $0.312 " 0 . D . \times 7.250 "$ long, are to be inserted in the ORR for irradiation and then dissolution studies will be made to determine processing procedures and handling techniques adaptable to plant operations.

Twenty-five Consolidated Edison-type fuel pins, fabricated by the Davidson Chemical Company, are being aged in an autoclave at $300^{\circ} \mathrm{C}$ and 2000 psig to produce an oxide coating which will closely simulate the surface condition of irradiated pins; these will also be used in dissolution tests.

\subsection{Mechanical Dejacketing Studies - G. A. West}

Detailed sketches of a device for decladding SRE fuels, NaK bonded U-rods clad with $10 \mathrm{mil}$ wall $304-\mathrm{I}$ stainless steel, are being drawn for approval of the method and possible future fabrication. The proposed decladding operation is to be performed with the element submerged in kerosene or some other suitable solvent. The end caps are to be removed with a special tubing cutting wheel, and hydraulic pressure and mechanical ram-rod techniques employed to remove the uranium slugs. The equipment includes provisions for discarding the $8 \mathrm{ft}$ length of cladding by spiral winding it into a 3 -in. dia, $1-1 / 4$ in. Iong cylinder. A preliminary cost estimate of $\$ 12,000$ was made for complete fabrication of the proposed equipment.

\subsection{Radiation Damage - G. A. West, J. C. Rose}

Glass coated steel specimens are being irradiated to $10^{10} \mathrm{r}$ gamma in the MTR gamma facility to determine the effect on various convex radii and stress-strain characteristics.; 


\subsection{WASTE PROCESSING}

J. J. Perona; C. W. Hancher

\subsection{Waste Reduction to Solid Problem}

The purpose of the waste reduction to solids problem of the waste processing development program was to develop suitable processing procedures for the treating of wastes from fuel reprocessing at ORNL prior to ultimate storage. At present the solid state is the only physical form accepted as safe for ultimate storage of radioactive wastes. The work for the preceding 30 days has been devoted to preliminary testing of a "25" $\left(\mathrm{Al}_{2}\left(\mathrm{NO}_{3}\right)_{3}\right)$ waste treating procedure. The hot cell was also tested to determine radiation levels in adjacent work areas when up to 1.5 curies of Co60 were placed in the cell.

\subsection{Treatment of "25" Wastes for Ultimate Disposal}

It is estimated that the radioactivity of "25" waste will be 2500 to 5000 curies/gal; the energy will be 44 to $90 \mathrm{Btu} / \mathrm{hr}$-gal or 12 to 26 watts/ gal.

The procedure for the treatment of this "25" waste might be: (1) evaporation, (2) neutralization, (3) drying, (4) off-gas cleaning, and (5) condensate clean-up.

The "25" waste (Table 7.I) was evaporated both after the addition of enough $\mathrm{NaOH}$ to bring the $\mathrm{pH}$ to $7.0(.19 \mathrm{~g} \mathrm{NaOH} / \mathrm{ml})$, and without $\mathrm{NaOH}$ neutralization.

\begin{tabular}{cc} 
Table 7.1. & Composition of "25" Waste \\
\hline Component & Concentration \\
\hline $\mathrm{Al}\left(\mathrm{NO}_{3}\right)_{3}$ & $1.6 \underline{\mathrm{M}}$ \\
$\mathrm{NH}_{4} \mathrm{NO}_{3}$ & $0.03 \mathrm{M}$ \\
$\mathrm{HNO}_{3}$ & $0.5 \mathrm{M}$ \\
\hline
\end{tabular}

The vapors were condensed and sampled. The $\mathrm{H}^{+}$ion concentration of the condensate from heating neutralized waste to $600^{\circ} \mathrm{C}$ was $0.5 \mathrm{M}$; the $\mathrm{H}^{+}$. ion of the acid waste condensate was $4.0 \mathrm{M}$.

During the acid evaporation $57 \%$ of the $\mathrm{NO}_{3}^{-}$ion reported to the condensate, and $19 \%$ to a $10 \% \mathrm{NaOH}$ trap in the off-gas line.

$$
3
$$




\subsection{Hot Cell Radiation Calibration}

Three cobalt 60 sources $(0.5,1.0$ and 1.5 curles) were placed into the cell inside a suitable carrier, and the cell was closed. Before the sources were removed from the carrier, 32 background radiation measurements were taken at various locations in Building 4505 (Figures 7.1, 7.2, and 7.3$)$. The sources were then removed one at a time and the radiation measurements reported (see Table 7.2 ). The weakest shielding area was the top of the cell; this. will be corrected by placing additional lead plate there. 
UNCLASSIFIED

ORNL-LR-DWG 33499

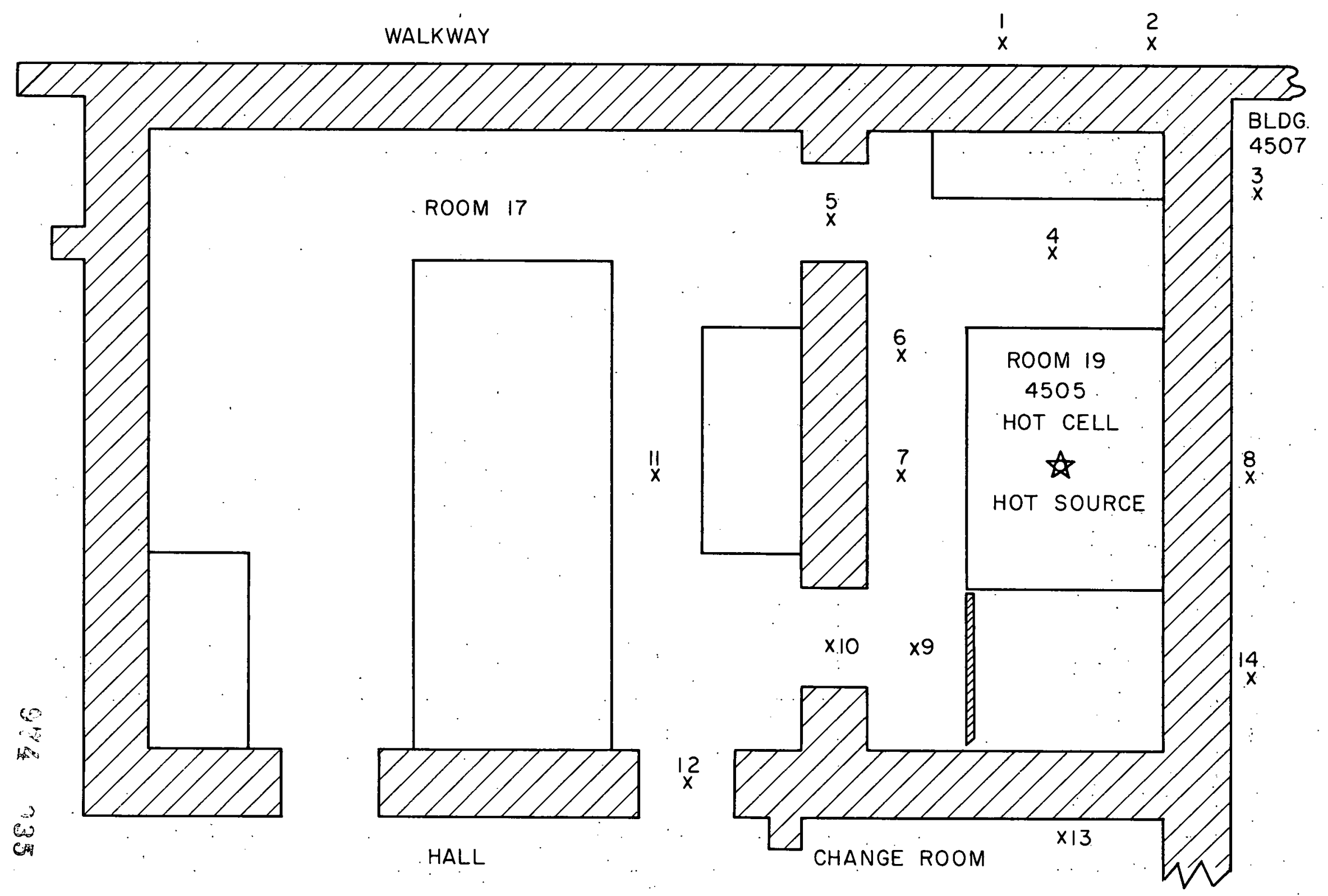

Fig. 7.I. Location of Radiation Measurements - First Floor, Bldg. 4505. 


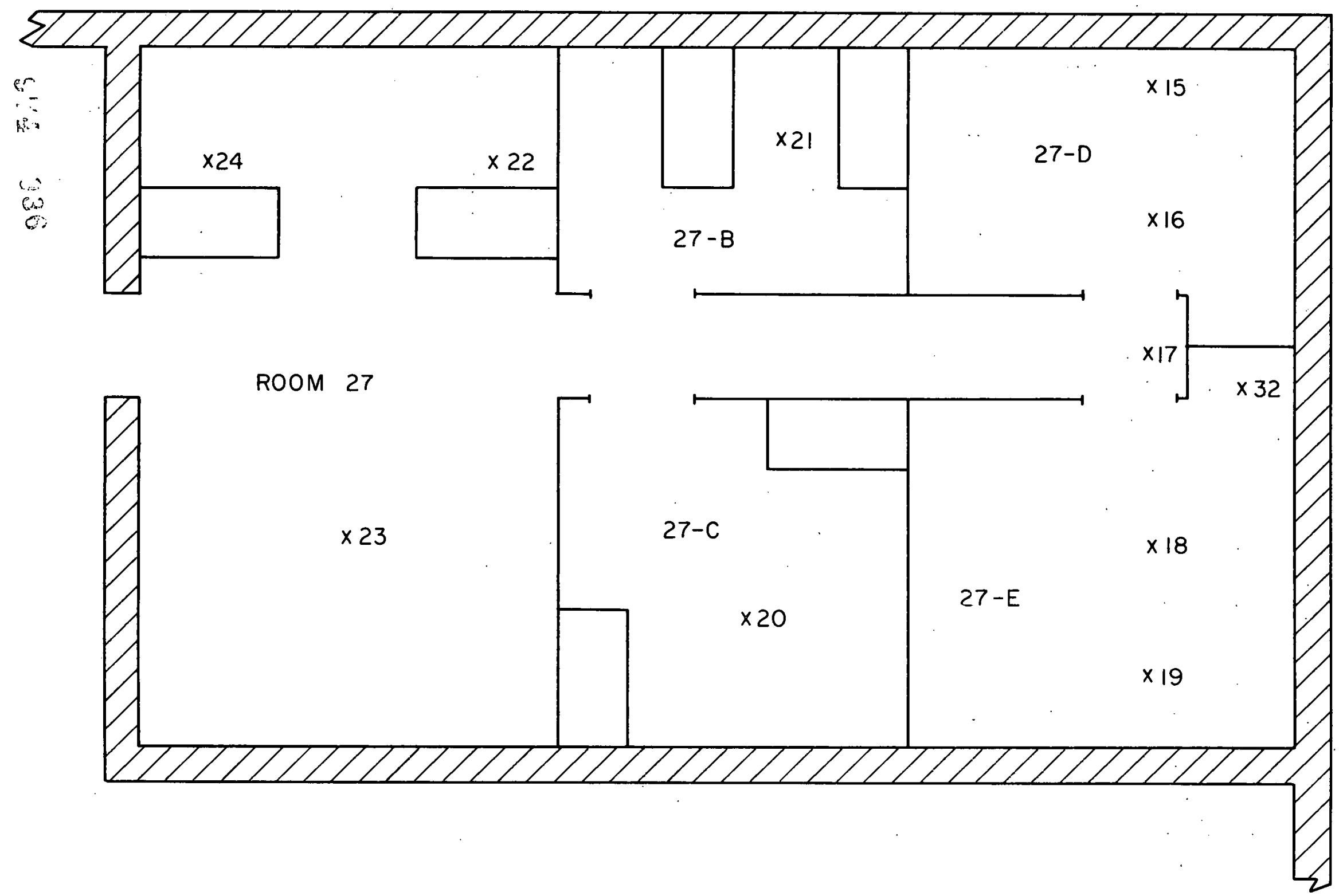

Fig. 7.2. Location of Radiation Measurements-Second Floor, Bldg. 4505. 


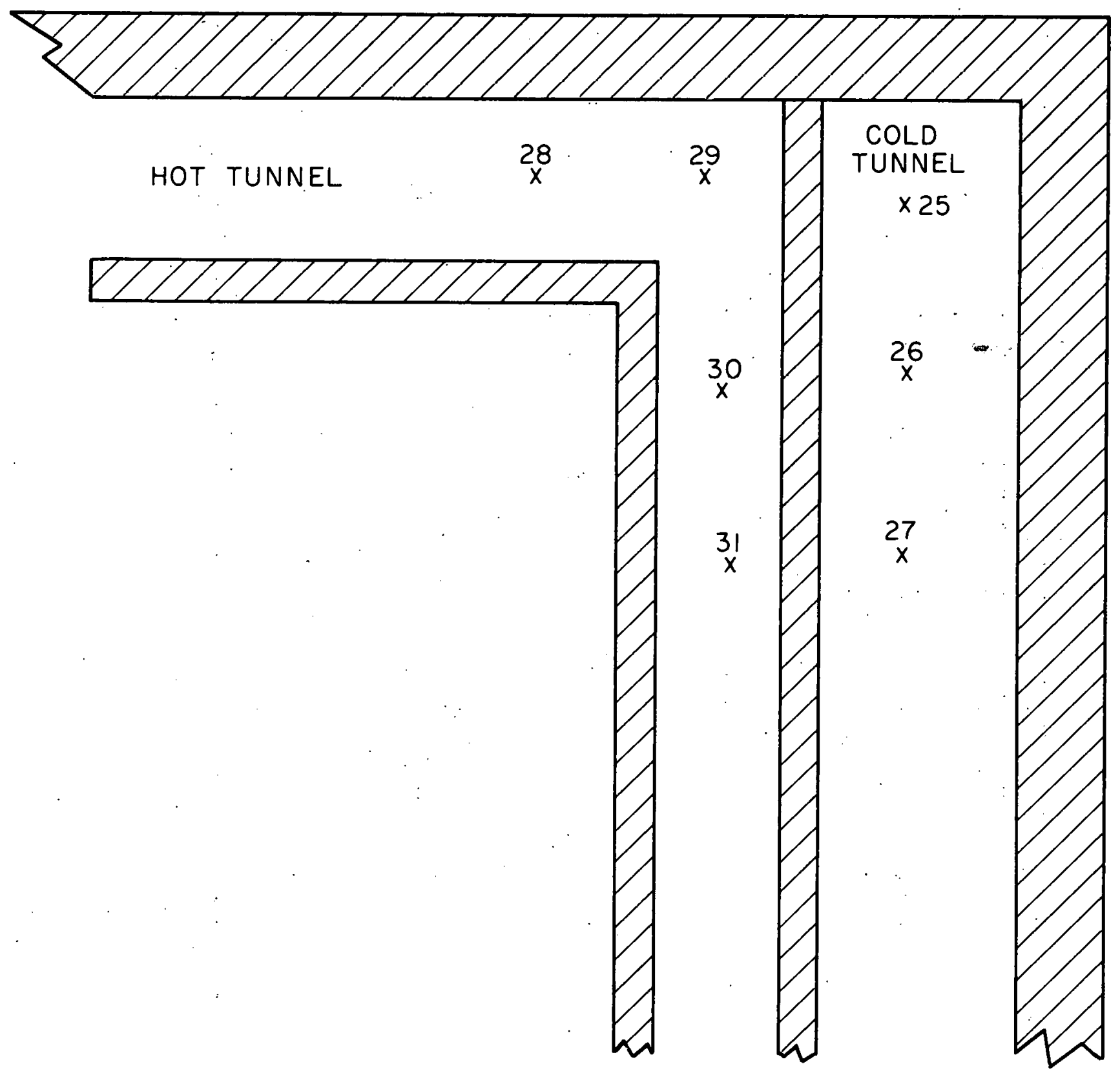

Fig. 7.3. Location of Radiation Measurements-Basement, Bldg. 4505.

$$
63 \%
$$


Table 7.2. Room 19 Hot Cell Radiation Shielding Test With $\mathrm{Co}^{60}$ Sources

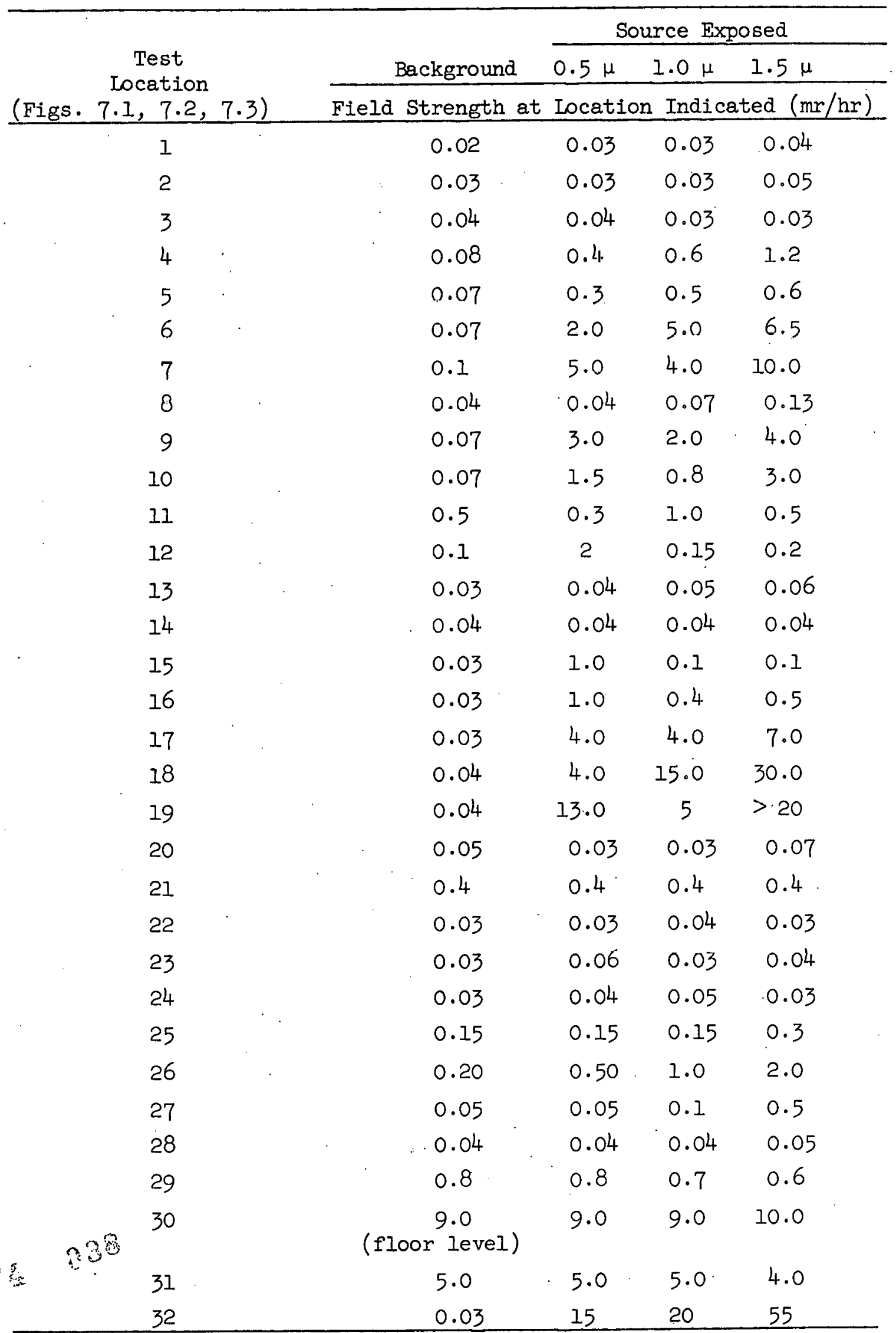




\section{DISTRIBUTION}

1. F: P. Baranowski (AEC Washington)

2. R. E. Blanco

3. J. C. Bresee

4. K. B. Brown $(Y-12)$

5. F. R. Bruce

6. L. P. Bupp (BW)

7. F. L. Culler

8. W. K. Eister

9. D. E. Ferguson

10. H. E. Goeller

11. A. T. Gresky

12. P. A. Haas

13. H. F. Johnson

14. S. H. Jury

15. F. Kerze (AEC Washington)

16. S. Lawroski (ANL)

17. J. A. Lieberman (AEC Washington)

18. R. B. Lindauer

19. J. T. Long

20. B. Manowitz (BNL)

21. J.W. Morris (SRP)

22. F. S. Patton, Jr. $(\mathrm{Y}-12)$

23-25。 E.M. Shank

26. M. J. Skinner

27. S. H. Smiley (ORGDP)

28. J. A. Sonia (Goodyear Atomic Corporation)

29. C.'E. Stevenson (ICPP)

30. C. D. Watson

31. C.E. Winters

32. M. E. Whatley

33-34. Central Research Library

35. Laboratory Records (RC)

36-39. Laboratory Records

40. Document Reference Section 